\title{
Electron-Induced Fragmentation of Methylated Formamides
}

\author{
Zhou Li ${ }^{1,2}$, M. Michele Dawley ${ }^{1}$, Ian Carmichael ${ }^{1}$, and Sylwia Ptasińska ${ }^{1,2 *}$ \\ ${ }^{1}$ Radiation Laboratory, University of Notre Dame, Notre Dame, IN 46556, USA \\ ${ }^{2}$ Department of Physics, University of Notre Dame, Notre Dame, IN 46556, USA
}

\section{Abstract}

All cationic fragments from70 eV electron ionization of $N, N$-dimethylformamide (DMF) and $\mathrm{N}$-methylformamide (NMF)aredetectedwitha quadrupole mass spectrometer and identifiedusing isotopically-labelled molecules. Ion efficiency curves near the threshold region $(5-20 \mathrm{eV})$ for all of the major cationic fragments aremeasured and fit with a Wannier-type function to determine their appearance energies (AEs).Possible reaction pathways for the formation of each observed cation areproposed, and the corresponding enthalpies $\left(\Delta H^{0} s\right)$ of reaction areevaluatedfromquantum chemical calculations using theGaussian09 computational quantum chemistry package. Our results suggest thathydrogen loss for both molecules occurs primarily from the carbonyl carbon.We confirm that hydrogen transfer from the carbonyl site to the nitrogen site occurs during amide bond cleavage. The resultantcations, $\mathrm{C}_{2} \mathrm{H}_{6} \mathrm{~N}^{+}$and $\mathrm{CH}_{4} \mathrm{~N}^{+}$, and their further fragments, formed by losingan $\mathrm{H}$ atom, $\mathrm{H}_{2}$, or $\mathrm{C}_{2} \mathrm{H}_{2}$, arefirst identified in mass spectra and furtherprobedby comparing the AEs with calculated $\Delta H^{0}$ s of all possible formationpathways. Additionally, we suggest that hydrogen transfer also occurs when the $\mathrm{N}-\mathrm{CH}_{3}$ bond breaks in DMF.This detailed study of the simplest molecule with the peptide linkage contributes to ourunderstanding of electron impact on peptide-like molecules.

*Corresponding author: Sylwia.Ptasinska.1@nd.edu.

\section{Introduction}

(a)

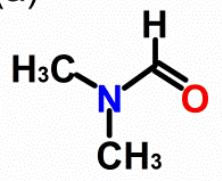

(b)<smiles>CNC=O</smiles>

FIG. 1. (a) N,N-dimethylformamide; (b) N-methylformamide (transconformer). 
$N, N$-dimethylformamide (DMF) and $N$-methylformamide (NMF), which are shown in Figure 1 , are two derivatives of formamide, which is the simplest molecule that has the $\mathrm{N}-\mathrm{C}=\mathrm{O}$ peptide linkage structure. Formamide has been discovered in the interstellar medium ${ }^{1-4}$ and is considered an important precursor in prebiotic chemistry. ${ }^{5-11}$ Besides these astrophysical and prebiotic interests, $N$-methylformamide is recognized as a potential chemosensitizer for combination chemotherapy. ${ }^{12-15} \mathrm{NMF}$ can actively enhance the success of radiation treatment on a human colon tumor in nude mice by significantly inhibiting the growth of the tumor. ${ }^{15}$ More interestingly, although NMFis a well-known chemosensitizer, DMF can suppress radiation-induced transformations in vitro. ${ }^{16}$ Thus, the number of methyl groups on thenitrogen site has a significant impact on the compounds' behavior upon irradiation in the cellular environment. Adetailed investigation of interactions between electrons, which are the most abundant secondary products of ionizing radiation, and methylated formamides may be critical to unveiling the essential factors that contribute to their differentialantitumor abilities.

Radiotherapy is currently the most widely adopted approachto treat tumorsthat have become a major health concern in modern society.Because it is well known that radiation can kill cancer cells and simultaneously damage normal cells,improved knowledge of the interaction of high energy radiation with cellular molecules is essential to enhance the efficiency of treatments to better target only the cancer cells. Once high energy radiationinteracts with living tissue,a series of complex reaction cascadeson the picosecond time scale produces vast amounts of reactive species, such as excited neutrals, ions, free radicals, secondary electrons, etc.Among all of the species, secondary electrons withenergy in the range of a few to tens of electronvoltsare the most abundant. For example,approximately $5 \times 10^{4}$ electrons can be generated for each energy quantum of a million electron volts deposited. ${ }^{17-19}$ The direct radiation damage that is caused by the energy depositionin cellular DNA and in the water molecules near or associated with this DNA only contributes partially tocellular inactivation, mutation, and transformation.Approximately two thirds of the radiation-induced effects are indirect,which are from diffusible free radicals, in particular, the hydroxyl radical. ${ }^{20-22} \mathrm{DMF}$ has been shown to have a comparable effect todimethyl sulfoxide (DMSO) in decreasing cell mortality under $\gamma$ irradiation. ${ }^{16}$ The radioprotective property of DMSO is generally attributed to its extremely strong ability to scavenge hydroxyl radicals. Because DMF is not as effective as DMSO in scavenging hydroxyl radicals, there mustbe other factors that account for the similar radioprotective effect of DMF. A detailedstudy of the interaction between DMF and secondary electrons and the consequent products can help to explain this phenomenon.

Several structural studies on bioactive compounds have suggested that $N$-alkyl moietieshave a significant influence on the antitumor activities of drugs. ${ }^{23-26}$ In addition, the saturated amine group is known for its unusual ability to direct the fragmentation pattern of the molecule. ${ }^{27,28}$ Thus, for compounds containing the group, $-\mathrm{NC}_{n} \mathrm{H}_{2 n+2}$, such as methylated formamide, methylated acetamide, methylated ureas, etc., ions with the formula of $\mathrm{C}_{n} \mathrm{H}_{2 \mathrm{n}+2} \mathrm{~N}^{+}$are 
usually the most dominantpeaks in the mass spectra. Loudon and Webb ${ }^{29}$ investigated the appearance energy (AE) of $\mathrm{C}_{2} \mathrm{H}_{6} \mathrm{~N}^{+}$and $\mathrm{CH}_{4} \mathrm{~N}^{+}$that are formed by the electron impact fragmentation of DMF and NMF. Because these AEs were lower $\left(1.30 \mathrm{eV}\right.$ for $\mathrm{C}_{2} \mathrm{H}_{6} \mathrm{~N}^{+},>1.9 \mathrm{eV}$ for $\mathrm{CH}_{4} \mathrm{~N}^{+}$) than the lowest energies for forming $\mathrm{C}_{2} \mathrm{H}_{6} \mathrm{~N}^{+}$and $\mathrm{CH}_{4} \mathrm{~N}^{+}$, they confirmed that the hydrogen relocated during the $(\mathrm{C}=\mathrm{O})-\mathrm{N}$ bond dissociation, and also that the ions, $\mathrm{C}_{2} \mathrm{H}_{6} \mathrm{~N}^{+}$and $\mathrm{CH}_{4} \mathrm{~N}^{+}$, were stabilized by isomerizing to $\mathrm{NHCH}_{3} \mathrm{CH}_{2}{ }^{+}$and $\mathrm{NH}_{2} \mathrm{CH}_{2}{ }^{+}$, respectively.

Here we report results from an electron ionization mass spectrometric study of NMF and DMF in the electron energy range of $5-20 \mathrm{eV}$. The cationic species of all of the major peaks in the mass spectra were identified by comparing them with the mass spectra of the deuterated compounds. The ion efficiency curves of the cations are reported, and the appearance energies were determined by fitting to a Wannier-type formula. ${ }^{30}$ Possible reaction pathways that lead to the formation of the cations are discussed by comparing the appearance energieswith estimates of the reaction enthalpies that were calculated using Gaussian09 software ${ }^{31}$. These calculations employ perhaps the most accurate composite method, W1BD, ${ }^{32}$ available in the package. Vertical ionization energetics were captured from high-level $\operatorname{CCSD}(\mathrm{T})^{33}$ calculations at geometries obtained from Density Functional Theory (DFT) usingthe B3LYP functional ${ }^{34}$ and a moderately flexible basis set, denoted $6-311+\mathrm{G}(\mathrm{d}, \mathrm{p}) .{ }^{35}$

\section{Experimental setup and data analysis}

The experimental setup for the present studywasdescribed in detail previously. ${ }^{36}$ Briefly, it consisted of a high vacuum chamber equipped with a Hiden $3 F$ Series quadrupole mass spectrometer (QMS)which detected the charged fragments' $\mathrm{m} / \mathrm{z}$ values and measured their ion efficiencies. The vacuum chamber had a base pressure of $\sim 10^{-9}$ mbar.A filament that was installed at the front of the mass spectrometer was used as the electron source. The resolution of the electron beam was $0.5 \mathrm{eV}$ (full width at half maximum), and the emission current was set to be $4 \mu \mathrm{A}$. Duringthe experiment, the vapor of the sample was dosed into the chamber via a gas line connected to a glass vial that contained the liquid sample.The vapor pressure is 5.16 mbar for DMF and 0.33 mbar for NMF at $25^{\circ} \mathrm{C}$. The liquid sample wasdegassed using the freezepump-thaw methodprior to experiments. The gasline was linked to the vacuum chamber via a leak valve, which was used to precisely control the dose of the sample vapor. Inside the chamber,the gas inlet, which was a metal tubule, was aimedat the entrance tothe QMS.N,Ndimethylformamide $\left(\mathrm{HCON}\left(\mathrm{CH}_{3}\right)_{2}, M=73 \mathrm{~g} / \mathrm{mol}\right)$ and $N$-methylformamide $\left(\mathrm{HCONHCH}_{3}\right.$, $M=59 \mathrm{~g} / \mathrm{mol}$ ) were both purchased from SigmaAldrich with stated puritiesof $99.8 \%$ and $99 \%$, respectively.The deuterated samples, $N, N$-dimethylformamide- $\mathrm{d}_{1} \quad\left(\mathrm{~d}_{1} \mathrm{DMF}\right), N, N$-dimethyl- $\mathrm{d}_{6}-$ formamide ( $\left.\mathrm{d}_{6} \mathrm{DMF}\right)$, and $\mathrm{N}$-methyl- $\mathrm{d}_{3}$-formamide $\left(\mathrm{d}_{3} \mathrm{NMF}\right)$, shown in Figure 2, were purchased from $\mathrm{C} / \mathrm{D} / \mathrm{N}$ Isotopes Inc., and all had an isotopic enrichment of 99 atom \% D. All of the samples were purchased asliquids at room temperature. All mass spectra reported in this work were measured at $70 \mathrm{eV}$. To make sure the mass spectra are solely from the samples, the mass spectra of the background at $70 \mathrm{eV}$ were also measured and subtracted appropriately. Ion efficienciesas a 
function of the electron energy were scanned from 5 to $20 \mathrm{eV}$ with signal onsets located in the region of 9 to $15 \mathrm{eV}$. Argon gas (with theionization energy of $15.759 \mathrm{eV})^{37}$ was used for calibration.All of the ion efficiency curves (for samples and calibration gases) were measured at a pressure of $\sim 1 \times 10^{-6}$ mbar.

(a)

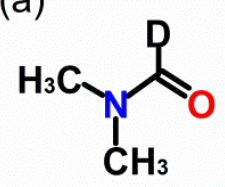

(b)

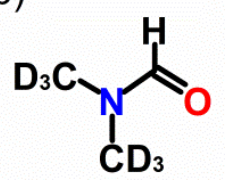

(c)

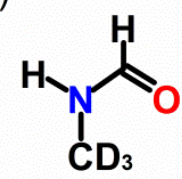

FIG. 2. (a) d DMF; (b) $d_{6}$ DMF; (c) $d_{3}$ NMF.

Wannierextended Wigner's formula ${ }^{38,30}$ and described the cross section as $\sigma=C(E-$ $A E)^{n}$,which is a function of the electron energy,E.In this formula, $C$ is the slope, $A E$ is the appearance energy and $n$ is an exponent that is only theoretically determined for hydrogen. This $n^{\text {th }}$ power rule was first introduced by Märk ${ }^{39}$ to determine threshold energies, and it thereafter became a widely used method. To extend the equation to the energy region below the threshold, we multiplied the right handside ofthe equation with a step function, $\theta(E-A E)$. Then, totake the limited resolution of the electron energy into account, we convoluted it with a Gaussian function, $\exp \left\{-E^{2} /\left(2 \rho^{2}\right)\right\} /(2 \pi)^{1 / 2}$, which is an approximation of the electron energy distribution with aresolution of $\rho$.After adding another constant, $B$, to remove the effect of the constant background, we obtained the equation to fit the ion efficiency curve, as provided below.

$$
\sigma=B+\left[C(E-A E)^{n} \theta(E-A E)\right] \frac{1}{\sqrt{2 \pi}} e^{-\frac{E^{2}}{2 \rho^{2}}}
$$

In some cases, the ion efficiency curve manifests two distinct thresholds. Thus, the fitting function was modified as the sum of two threshold fitting functions, as shown below.

$$
\sigma=B+\left[C\left(E-A E_{1}\right)^{n} \theta\left(E-A E_{1}\right)\right] \frac{1}{\sqrt{2 \pi}} e^{-\frac{E^{2}}{2 \rho^{2}}}+\left[C\left(E-A E_{2}\right)^{n} \theta\left(E-A E_{2}\right)\right] \frac{1}{\sqrt{2 \pi}} e^{-\frac{E^{2}}{2 \rho^{2}}}
$$

The fittings were performed using the OriginPro 8.6 software package with the $\chi^{2}$ tolerance set to be $10^{-6}$. The resolution, $\rho$, was fixed at $0.5 \mathrm{eV}$, and the appearance energy, $A E$, exponent, $n$, and slope, $C$, were all optimized by minimizing the mean square deviation during the fitting. All of the $R^{2}$ values for the fitting performed in this work are $\geq 0.99$. The energy calibration was performed with $\mathrm{Ar}^{+}$, as stated above. The uncertainties of the obtained $A E$ values in Table 1 are a combination of the energy calibration $( \pm 0.1 \mathrm{eV})$ and the standard errors that wereprovided by the fitting.

Because the experiment was performed at room temperature (approximately $25^{\circ} \mathrm{C}$ ), for each possible reaction pathway, the standard enthalpy (heat) of reaction, $\Delta H^{0}$,was calculated and then compared with the $A E$ values. The $\Delta H^{0}$ values were obtained from $\Delta H^{0}=\sum \Delta H_{f}^{0}$ (products) $\Sigma \Delta H_{f}^{0}$ (reactants). The computationalquantum chemistry package, Gaussian09, ${ }^{31}$ was used to 
optimize the structure of products and reactants, and evaluatethe standard enthalpies fortheseoptimized structures. Geometries were first optimized using the DFT approach withthe B3LYP functional ${ }^{34}$ and a moderately flexiblebasis set denoted6-311+G(d,p). ${ }^{35}$ Then the W1BD procedure, ${ }^{32}$ the most accurate composite method available in the Gaussian 09 package, ${ }^{31}$ was used to calculate the enthalpies, except for $\mathrm{H}$ of which the enthalpy was calculated using cbs-qb3 method. ${ }^{40}$ Methyl-substituted amidogen radicals have been reported with diverse ionization energies, for example, the ionization energy of $\mathrm{NHCH}_{3}{ }^{+}$is reported to have an upper and lower bond of 10.6 and $9.9 \mathrm{eV}$, respectively. ${ }^{41}$ The W1BD calculation in this work gives an ionization energy of $9.83 \mathrm{eV}$ for triplet ground state $\mathrm{NHCH}_{3}{ }^{+}$. This result is in good agreement with Wright and Miller's calculation $(9.8 \pm 0.1 \mathrm{eV})^{41}$. Thus,calculationsperformed in this work provide reliable theoretical estimates for reaction enthalpies.

$\mathrm{N}$-methylformamide typicallyexists as a mixture of cis and trans rotational conformers. These two isomers are separated by a torsional barrier of ca. $70 \mathrm{~kJ} \cdot \mathrm{mol}^{-1}$ around the centralC-N bond. According to previous work, the trans isomer predominates ( $92 \%$ trans, $8 \%$ cis)at $35^{\circ} \mathrm{C}$, ${ }^{42}$ and the difference in the energy and ionization energy of the two isomers is less than $0.1 \mathrm{eV},{ }^{43}$ whichlies within the range of the uncertainty due to our calibration method. Thus, the cis configuration was ignoredin these calculations for simplicity.

\section{Results and Discussion}

\subsection{Mass spectra and appearance energy values}

Figure 3 presents mass spectra of DMF and NMF and their deuterated homologs, $\mathrm{d}_{1} \mathrm{DMF}$ $\left(\mathrm{DCON}\left(\mathrm{CH}_{3}\right)_{2}\right), \mathrm{d}_{6} \mathrm{DMF}\left(\mathrm{HCON}\left(\mathrm{CD}_{3}\right)_{2}\right)$, and $\mathrm{d}_{3} \mathrm{NMF}\left(\mathrm{HCONHCD}_{3}\right)$, at an electron energy of $70 \mathrm{eV}$. The parent cations and the major cationic fragments are marked in the mass spectra and their relative intensities are consistent with those reported previously. ${ }^{44}$

The major cations' formulas were identifiedassuming that the deuterated molecules' fragmentation patterns are the same as those for the non-deuterated molecules,i.e., for each cation that resultsfrom DMF fragmentation, its deuterated counterpart will be observedat a similar intensity due to the fragmentation of deuterated DMFs. Therefore, by matching the cations in the DMF mass spectrum with those fromits deuterated counterparts in the spectra of $\mathrm{d}_{1} \mathrm{DMF}$ and $\mathrm{d}_{6} \mathrm{DMF}$, the number of hydrogen atoms in the cations can be determinedand assignments reliably made.The peaks at 15, 58, and $73 \mathrm{amu}$ in the DMF mass spectrawere easy to determine asCH${ }_{3}{ }^{+}$, [DMF- $\left.\mathrm{CH}_{3}\right]^{+}$, and $\mathrm{DMF}^{+}$, respectively, and their counterparts in the $\mathrm{d}_{1} \mathrm{DMF}$ mass spectra are $\mathrm{CH}_{3}{ }^{+}(15 \mathrm{amu}),\left[\mathrm{d}_{1} \mathrm{DMF}-\mathrm{CH}_{3}\right]^{+}$(59 amu), and $\mathrm{d}_{1} \mathrm{DMF}^{+}$(74 amu). In $\mathrm{d}_{6} \mathrm{DMF}$, the

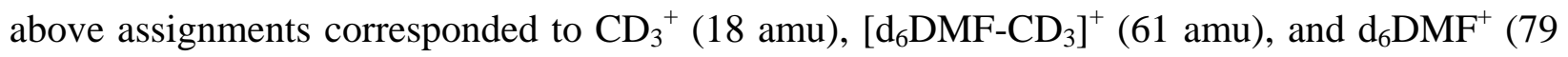
amu). The peaks at 42 and $44 \mathrm{amu}$ in DMF can be assigned to $\mathrm{OCN}^{+}, \mathrm{H}_{2} \mathrm{CON}^{+}$or $\mathrm{C}_{2} \mathrm{H}_{4} \mathrm{~N}^{+}$and to $\mathrm{C}_{2} \mathrm{H}_{6} \mathrm{~N}^{+}$, respectively. Their counterparts are 42 and $45 \mathrm{amu}$ in $\mathrm{d}_{1} \mathrm{DMF}$ and 46 and 49 amu in $\mathrm{d}_{6} \mathrm{DMF}$, respectively. Because the masses of the deuterated molecules are increased by 4 and $5 \mathrm{amu}$ in $\mathrm{d}_{6} \mathrm{DMF}$, the two cations contain at least 4 and 5 hydrogen atoms. Thus, the peaks at 42 and $44 \mathrm{amu}$ in the DMF mass spectrarepresent $\mathrm{C}_{2} \mathrm{H}_{4} \mathrm{~N}^{+}$, and $\mathrm{C}_{2} \mathrm{H}_{6} \mathrm{~N}^{+}$, rather than $\mathrm{OCN}^{+}$and 
$\mathrm{H}_{2} \mathrm{CON}^{+}$. In some cases, one single peak in DMF branches into multiple peaks in the deuterated mass spectra, e.g., the peak at $18 \mathrm{amu}$ in DMF. Its corresponding peaks in the $\mathrm{d}_{1} \mathrm{DMF}$ mass spectrum are at 18 and $19 \mathrm{amu}$, and in $\mathrm{d}_{6} \mathrm{DMF}$,they are at 21 and $22 \mathrm{amu}$.Because the counterparts ind ${ }_{6} \mathrm{DMF}$ are 3 and 4 amu heavier, there are more than two hydrogen atoms in this cation. Thus, the peak at 18 amu does not represent $\mathrm{H}_{2} \mathrm{O}$, but instead $\mathrm{NH}_{4}$. The peaks at 28, 29, and $30 \mathrm{amu}$ in the DMF mass spectrumcan be $\mathrm{CO}^{+}, \mathrm{HCO}^{+}$and $\mathrm{H}_{2} \mathrm{CO}^{+}$or $\mathrm{CH}_{2} \mathrm{~N}^{+}, \mathrm{CH}_{3} \mathrm{~N}^{+}$and $\mathrm{CH}_{4} \mathrm{~N}^{+}$. By measuring the deuterated mass spectra, their formulas were determined, as shown in Figure 3(a) andtheir assignments are explained below. The peak at 28 amu represents both $\mathrm{CO}^{+}$ and $\mathrm{CH}_{2} \mathrm{~N}^{+}$, and this is because there are peaks at 28 and $30 \mathrm{amu}$ in $\mathrm{d}_{6} \mathrm{DMF}$ that can only be due to $\mathrm{CO}^{+}$and $\mathrm{CND}_{2}{ }^{+}$, respectively.The peak at 29 amu represents $\mathrm{HCO}^{+}$, and this is because if there was $\mathrm{CH}_{3} \mathrm{~N}^{+}$, then there would be peaks at $31\left(\mathrm{CHD}_{2} \mathrm{~N}^{+}\right)$or $32\left(\mathrm{CD}_{3} \mathrm{~N}^{+}\right)$amu in the $\mathrm{d}_{6} \mathrm{DMF}$ mass spectrum; however, these peaks are not present. The peak at $30 \mathrm{amu}$ is attributed to $\mathrm{CH}_{4} \mathrm{~N}^{+}$, and this is because its counterpartin $\mathrm{d}_{6} \mathrm{DMF}$ is at $33 \mathrm{amu}$, which suggests at least 3 hydrogen atoms in this cation. In addition to all of the major cationic fragments discussed above, another cation species that ispresent in DMF mass spectra is [DMF-H] ${ }^{+}(72 \mathrm{amu})$, which corresponds to $\left[\mathrm{d}_{1} \mathrm{DMF}^{\mathrm{D}}\right]^{+}(72 \mathrm{amu})$ in $\mathrm{d}_{1} \mathrm{DMF}$ and $\left[\mathrm{d}_{6} \mathrm{DMF}-\mathrm{H}\right]^{+}$(78 amu) in $\mathrm{d}_{6} \mathrm{DMF}$.

The mass spectrum of NMF is shown in Figure 3(b), and it has fewer peaks than DMF. The major cations resulting from the electron-induced NMF fragmentation were also identified. In the mass spectra of NMF, the most intense two peaks are $30 \mathrm{amu}\left(\mathrm{CH}_{4} \mathrm{~N}^{+}\right)$and $58 \mathrm{amu}\left(\mathrm{NMF}^{+}\right)$ that are formed due to amide bond cleavage and single ionization of the parent molecule, respectively.The deuterated counterparts of $\mathrm{CH}_{4} \mathrm{~N}^{+}$in the $\mathrm{d}_{3} \mathrm{NMF}$ mass spectrum are at $32 \mathrm{amu}$ $\left(\mathrm{CD}_{2} \mathrm{H}_{2} \mathrm{~N}^{+}\right)$and $33 \mathrm{amu}\left(\mathrm{CD}_{3} \mathrm{HN}^{+}\right)$. The fact that the intensity of the peak at $32 \mathrm{amu}\left(\mathrm{CD}_{2} \mathrm{H}_{2} \mathrm{~N}^{+}\right)$ is much higher than $33 \mathrm{amu}\left(\mathrm{CD}_{3} \mathrm{HN}^{+}\right)$indicates that thereis a dominant pathway in which a hydrogen atom transfers to a nitrogen site when the $(\mathrm{C}=\mathrm{O})-\mathrm{N}$ bond breaks. The intensity of the peak at 29 amu $\left(\mathrm{HCO}^{+}, \mathrm{CHDN}^{+}\right)$in the $\mathrm{d}_{3} \mathrm{NMF}$ mass spectrum is much higher than the peak at $29 \mathrm{amu}\left(\mathrm{HCO}^{+}, \mathrm{CH}_{3} \mathrm{~N}^{+}\right)$in the NMF mass spectrum. This suggeststhat $\mathrm{CHDN}^{+}$contributes significantly to the peak at 29 amu in $\mathrm{d}_{3} \mathrm{NMF}$. Thus, there is a significant yield of $\mathrm{CH}_{2} \mathrm{~N}^{+}$in the fragmentation of NMF, andthe peak at $28 \mathrm{amu}$ in NMF represents a mixture of $\mathrm{CH}_{2} \mathrm{~N}^{+}$and $\mathrm{CO}^{+}$.The peak at $29 \mathrm{amu}$ in the NMF mass spectrum represents $\mathrm{CH}_{3} \mathrm{~N}^{+}$and $\mathrm{HCO}^{+}$, and the deuterated counterparts are $\mathrm{CD}_{3} \mathrm{~N}^{+}$(32 amu), $\mathrm{CHD}_{2} \mathrm{~N}^{+}(31 \mathrm{amu}), \mathrm{CH}_{2} \mathrm{DN}^{+}(30 \mathrm{amu})$ and $\mathrm{HCO}^{+}$ $(29 \mathrm{amu})$ in the $\mathrm{d}_{3} \mathrm{NMF}$ mass spectrum. $\mathrm{CH}_{3}{ }^{+}(15 \mathrm{amu})$ and $[\mathrm{NMF}-\mathrm{H}]^{+}$(58 amu) are also shown in the mass spectra of NMF, and their counterparts in $\mathrm{d}_{3} \mathrm{NMF}$ are $\mathrm{CD}_{3}{ }^{+},\left[\mathrm{d}_{3} \mathrm{NMF}-\mathrm{H}\right]^{+}$, and $\left[\mathrm{d}_{3} \mathrm{NMF}-\mathrm{D}\right]^{+}$, respectively.

The appearance energies (AEs) of all of the major cations, including uncertainties, were measured and are listed in TablesI and II. The standard enthalpies of reaction, $\Delta H^{0} \mathrm{~s}$ (in eV), for the formation of these cations directly from the fragmentation of the molecule (AB $+\mathrm{e}^{-} \rightarrow \mathrm{A}^{+}+\mathrm{B}$ $+2 \mathrm{e}^{-}$) via different pathways are shown in the tables. The $\Delta H^{0}$ values represent the lowest energy requirement for the incoming electrons to trigger the corresponding fragmentation reactions. The predicted reaction pathways leading to each cationic fragment are identified with greyshading in the tables. The reaction pathways are discussed in the following sections. 
(a)

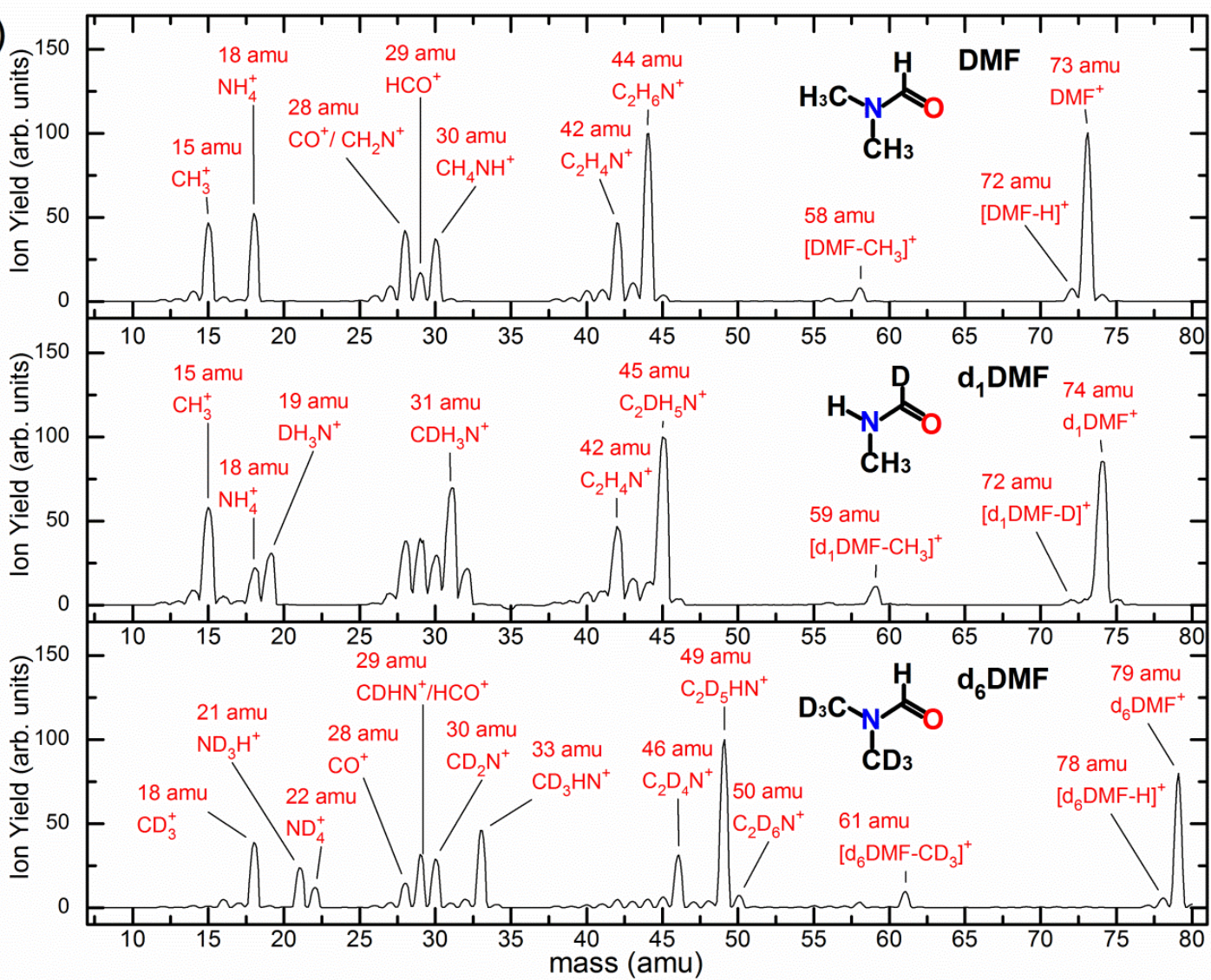

(b)

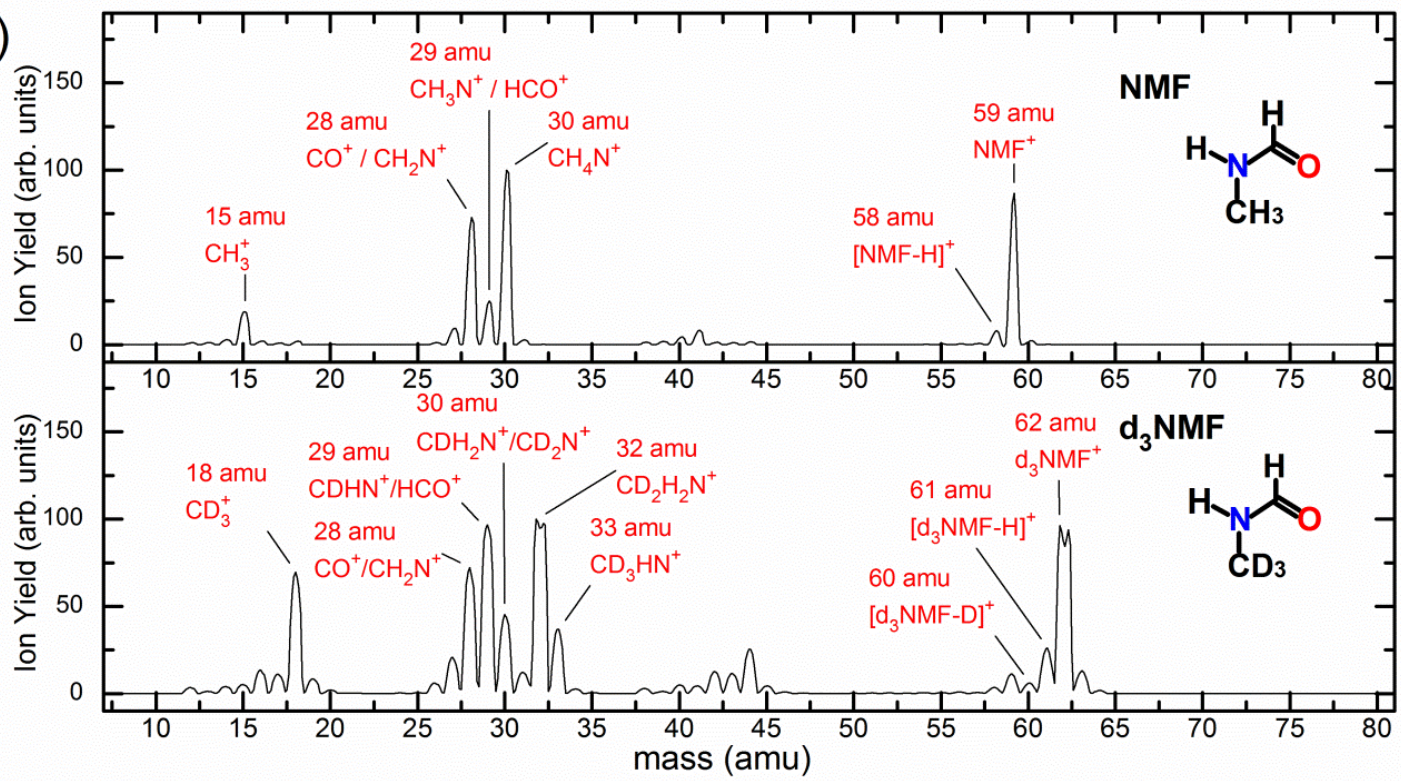

FIG.3. (a) Mass spectra of DMF and its deuterated isotopologues, $d_{1} D M F$ and $d_{6} D M F$; (b) Mass spectra of NMF and its deuterated isotopologue, $d_{3} \mathrm{NMF}$.

TABLE I. Appearance energies ofcationic fragments from DMF and calculated enthalpies of formation, $\Delta \mathbf{H}^{0}$, of major reaction pathways.

\begin{tabular}{llllll}
\hline \hline $\begin{array}{l}\mathrm{m} / \mathrm{z} \\
(\mathrm{amu})\end{array}$ & $\begin{array}{l}\text { This work } \\
(\mathrm{eV})\end{array}$ & $\begin{array}{l}\text { Other work } \\
(\mathrm{eV})\end{array}$ & Cationic fragment & $\begin{array}{l}\text { Neutral } \\
\text { fragment(s) }\end{array}$ & $\Delta \mathrm{H}^{0}(\mathrm{eV})$ \\
\hline
\end{tabular}




\begin{tabular}{|c|c|c|c|c|c|}
\hline \multirow[t]{2}{*}{72} & \multirow[t]{2}{*}{$11.09 \pm 0.1$} & \multirow[t]{2}{*}{$11.35^{\mathrm{a}}$} & [DMF-H] $^{+}$(carbonyl site) & $\mathrm{H}$ & 10.73 \\
\hline & & & 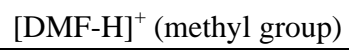 & $\mathrm{H}$ & 10.76 \\
\hline \multirow[t]{3}{*}{58} & \multirow[t]{3}{*}{$10.98 \pm 0.2$} & & $\mathrm{HCONCH}_{3}^{+}$ & $\mathrm{CH}_{3}$ & 13.95 \\
\hline & & & $\mathrm{HCONHCH}_{2}^{+}$ & $\mathrm{CH}_{3}$ & 10.46 \\
\hline & & & $\mathrm{OCNHCH}_{3}^{+}$ & $\mathrm{CH}_{3}$ & 10.32 \\
\hline \multirow[t]{3}{*}{44} & \multirow[t]{3}{*}{$10.71 \pm 0.1$} & \multirow{3}{*}{$\begin{array}{l}11.60^{\mathrm{a}}, \\
11.6 \pm 0.1^{\mathrm{b}}\end{array}$} & \multirow{3}{*}{$\begin{array}{l}\mathrm{N}\left(\mathrm{CH}_{3}\right)_{2}{ }^{+} \\
\mathrm{NHCH}_{2} \mathrm{CH}_{3}{ }^{+}\end{array}$} & $\mathrm{HCO}$ & 13.03 \\
\hline & & & & $\mathrm{CO}, \mathrm{H}$ & 10.48 \\
\hline & & & & $\mathrm{HCO}$ & 9.80 \\
\hline \multirow[t]{6}{*}{43} & \multirow{6}{*}{$\begin{array}{l}10.20 \pm 0.1 \\
16.37 \pm 0.2\end{array}$} & & \multirow[t]{2}{*}{$\mathrm{HCON}^{+}$} & $\mathrm{C}_{2} \mathrm{H}_{6}$ & 14.18 \\
\hline & & & & $2 \times \mathrm{CH}_{3}$ & 18.10 \\
\hline & & & \multirow[t]{2}{*}{$\mathrm{CONH}^{+}$} & $\mathrm{C}_{2} \mathrm{H}_{6}$ & 11.76 \\
\hline & & & & $2 \times \mathrm{CH}_{3}$ & 15.68 \\
\hline & & & $\mathrm{NCH}_{2} \mathrm{CH}_{3}^{+}$ & $\mathrm{CO}, \mathrm{H} 2$ & 10.85 \\
\hline & & & $\mathrm{NHCH}_{2} \mathrm{CH}_{2}^{+}$ & $\mathrm{CO}, \mathrm{H} 2$ & 10.09 \\
\hline \multirow[t]{6}{*}{42} & \multirow[t]{6}{*}{$11.59 \pm 0.3$} & & \multirow[t]{2}{*}{$\mathrm{OCN}^{+}$} & $\mathrm{H}, \mathrm{C}_{2} \mathrm{H}_{6}$ & 17.96 \\
\hline & & & & $\mathrm{CH}_{3}, \mathrm{CH}_{4}$ & 17.32 \\
\hline & & & \multirow[t]{2}{*}{$\mathrm{NCH}_{2} \mathrm{CH}_{2}{ }^{+}$} & HCO, H2 & 11.72 \\
\hline & & & & $\mathrm{CO}, \mathrm{H}, \mathrm{H} 2$ & 12.41 \\
\hline & & & \multirow[t]{2}{*}{$\mathrm{NHCHCH}_{2}{ }^{+}$} & $\mathrm{HCO}, \mathrm{H} 2$ & 12.80 \\
\hline & & & & $\mathrm{CO}, \mathrm{H}, \mathrm{H} 2$ & 13.48 \\
\hline \multirow[t]{2}{*}{30} & \multirow[t]{2}{*}{$12.08 \pm 0.2$} & & $\mathrm{NHCH}_{3}^{+}$ & $\mathrm{CO}, \mathrm{CH}_{3}$ & 14.04 \\
\hline & & & $\mathrm{NH}_{2} \mathrm{CH}_{2}{ }^{+}$ & $\mathrm{CO}, \mathrm{CH}_{3}$ & 10.16 \\
\hline \multirow[t]{4}{*}{29} & \multirow[t]{4}{*}{$12.31 \pm 0.4$} & \multirow{4}{*}{$\begin{array}{l}14.50^{\mathrm{a}}, \\
14.3 \pm 0.1^{\mathrm{b}}\end{array}$} & \multirow[t]{2}{*}{$\mathrm{HCO}^{+}$} & $\mathrm{N}\left(\mathrm{CH}_{3}\right)_{2}$ & 12.22 \\
\hline & & & & $\mathrm{NHCH}_{2} \mathrm{CH}_{3}$ & 12.15 \\
\hline & & & $\mathrm{NH}_{2} \mathrm{CH}^{+}$ & $\mathrm{CO}, \mathrm{CH}_{4}$ & 11.10 \\
\hline & & & $\mathrm{NHCH}_{2}^{+}$ & $\mathrm{CO}, \mathrm{CH}_{4}$ & 10.96 \\
\hline \multirow[t]{5}{*}{28} & \multirow[t]{5}{*}{$13.07 \pm 0.2$} & & $\mathrm{CO}^{+}$ & $\mathrm{NH}\left(\mathrm{CH}_{3}\right)_{2}$ & 14.71 \\
\hline & & & $\mathrm{NCH}_{2}{ }^{+}$ & $\mathrm{CO}, \mathrm{CH}_{3}, \mathrm{H}_{2}$ & 15.31 \\
\hline & & & & $\mathrm{CH}_{4}, \mathrm{HCO}$ & 14.60 \\
\hline & & & $\mathrm{NHCH}^{+}$ & $\mathrm{CO}, \mathrm{CH}_{3}, \mathrm{H}_{2}$ & 12.23 \\
\hline & & & & $\mathrm{CH}_{4}, \mathrm{HCO}$ & 11.52 \\
\hline \multirow[t]{3}{*}{18} & \multirow[t]{3}{*}{$12.75 \pm 0.2$} & & \multirow[t]{3}{*}{$\mathrm{NH}_{4}^{+}$} & $\mathrm{CO}, \mathrm{CHCH}, \mathrm{H}$ & 12.05 \\
\hline & & & & $\mathrm{HCO}, \mathrm{CHCH}$ & 11.36 \\
\hline & & & & $\mathrm{CO}, \mathrm{CH}_{2} \mathrm{CH}$ & 10.64 \\
\hline 15 & $\begin{array}{l}10.50 \pm 0.3 \\
13.90 \pm 0.4\end{array}$ & & $\mathrm{CH}_{3}^{+}$ & $\mathrm{OCHNCH}_{3}$ & 13.82 \\
\hline
\end{tabular}

${ }^{\mathrm{a}}$ Data is from reference ${ }^{29}$.

${ }^{\mathrm{b}}$ Data is from reference ${ }^{45}$.

TABLE II. Appearance energies of the cationic fragments from NMF and calculated enthalpies of formation, $\Delta \mathbf{H}^{0}$, of major reaction pathways.

\begin{tabular}{llllll}
\hline \hline $\begin{array}{l}\mathbf{m} / \mathbf{z} \\
(\mathbf{a m u})\end{array}$ & $\begin{array}{l}\text { This work } \\
(\mathbf{e V})\end{array}$ & $\begin{array}{l}\text { Other work } \\
(\mathbf{e V})\end{array}$ & Cationic fragment & $\begin{array}{l}\text { Neutral } \\
\text { fragment(s) }\end{array}$ & $\Delta \mathbf{H}^{\mathbf{0}}(\mathbf{e V})$ \\
\hline $\mathbf{5 8}$ & $11.27 \pm 0.1$ & $11.20^{\mathrm{a}}$ & {$[\mathrm{NMF}-\mathrm{H}]^{+}$(carbonyl site) } & $\mathrm{H}$ & 11.07 \\
& & & $\begin{array}{l}{[\mathrm{NMF}-\mathrm{H}]^{+} \text {(methyl group) }} \\
{[\mathrm{NMF}-\mathrm{H}]^{+} \text {(nitrogen site) }}\end{array}$ & $\mathrm{H}$ & 11.21 \\
& & & & 14.70 \\
\hline
\end{tabular}




\begin{tabular}{llllll}
\hline 30 & $10.06 \pm 0.1$ & $11.65^{\mathrm{a}}$ & $\mathrm{NHCH}_{3}{ }^{+}$ & $\mathrm{HCO}$ & 14.10 \\
& & & $\mathrm{NH}_{2} \mathrm{CH}_{2}{ }^{+}$ & $\mathrm{HCO}$ & 10.22 \\
& & & $\mathrm{H}, \mathrm{CO}$ & 10.90 \\
\hline $\mathbf{2 9}$ & $11.90 \pm 0.2$ & $12.40^{\mathrm{a}}$ & $\mathrm{HCO}^{+}$ & $\mathrm{NHCH}_{3}$ & 12.42 \\
& & & $\mathrm{NH}_{2} \mathrm{CH}_{2}$ & 12.11 \\
& & $\mathrm{NH}_{2} \mathrm{CH}^{+}$ & $\mathrm{CO}, \mathrm{H}_{2}$ & 11.87 \\
& & $\mathrm{NHCH}_{2}{ }^{+}$ & $\mathrm{CO}, \mathrm{H}_{2}$ & 11.73 \\
\hline $\mathbf{2 8}$ & $13.71 \pm 0.2$ & $\mathrm{CO}^{+}$ & $\mathrm{NH}_{2} \mathrm{CH}_{3}$ & 14.83 \\
& & $\mathrm{NCH}_{2}{ }^{+}$ & $\mathrm{HCO}, \mathrm{H}_{2}$ & 15.38 \\
& & $\mathrm{NHCH}^{+}$ & $\mathrm{HCO}, \mathrm{H}_{2}$ & 12.29 \\
& & $\mathrm{NH}_{2} \mathrm{C}^{+}$ & $\mathrm{HCO}, \mathrm{H}_{2}$ & 14.51 \\
\hline \hline
\end{tabular}

${ }^{\mathrm{a}}$ Data is from reference ${ }^{29}$.

\subsection{Ionization energies of NMF and DMF}
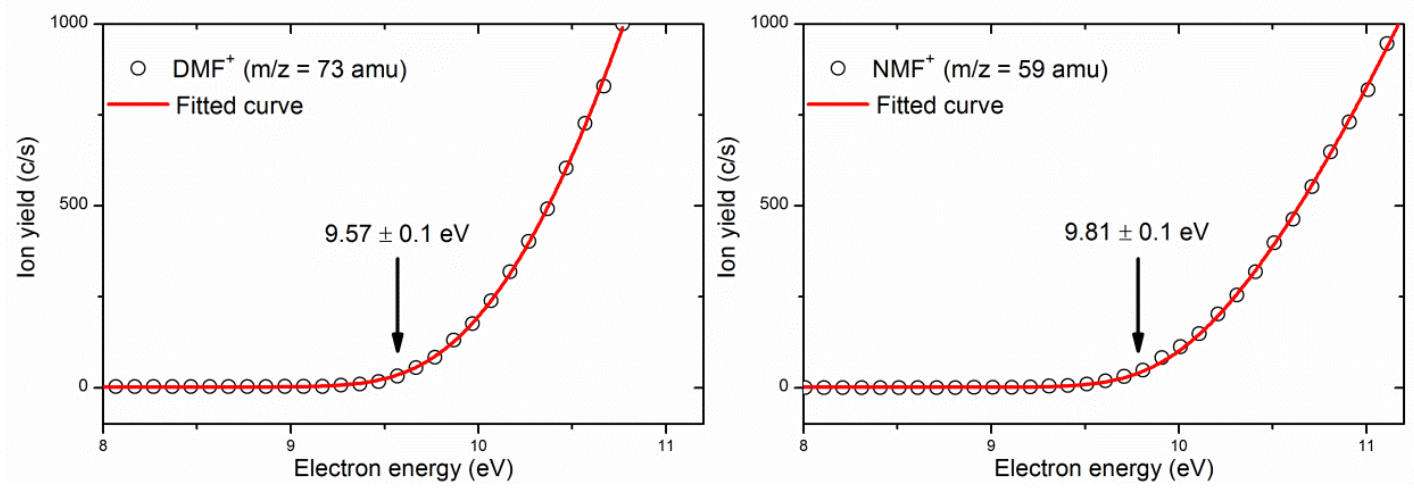

FIG. 4. Ion efficiency curves for the 73 amu $\left(\mathrm{DMF}^{+}\right)$cation from DMF (left) and 59 amu (NMF ${ }^{+}$) cation from NMF (right).

The ionization energy is determined by the minimum energy required to remove one electron from the molecule's highest occupied orbital.The ion efficiency curves near the threshold region for $\mathrm{NMF}^{+}$and $\mathrm{DMF}^{+}$were measured and fit with a Wannier-type function as shown in Figure 4. The two highest occupied orbitals in DMF and NMF are the carbonyl oxygen lone pair $\left(\mathrm{n}_{0}\right)$ and the nonbonding antisymmetric $\pi_{2}$ orbital, which consist of the nitrogen lone pair and carbonyl double bond orbitals, as seen in Figure 5. In a photoelectron spectroscopy study, ${ }^{46}$ the ionization potentials of DMF were determined to be $9.77 \mathrm{eV}$ (vertical) and $\geq 9.40 \mathrm{eV}$ (adiabatic) for the $\mathrm{n}_{0}$ orbital and $9.25 \mathrm{eV}$ (vertical) and $9.14 \mathrm{eV}$ (adiabatic) for the $\pi_{2}$ orbital.Single point calculations at $\operatorname{CCSD}(\mathrm{T})$ /aug-cc-pVTZ level,at the appropriate relaxed geometries obtained by the abovementioned DFT approach, give ionization energies of $9.81 \mathrm{eV}$ (vertical) and $9.50 \mathrm{eV}$ (adiabatic) for the $\mathrm{n}_{0}$ orbital and $9.32 \mathrm{eV}$ (vertical) and $9.14 \mathrm{eV}$ (adiabatic) for the $\pi_{2}$ orbital, which agree with the experimental data very well.For NMF, the $n_{0}$ orbital ionization potential was measured at $10.05 \mathrm{eV}$ (vertical and adiabatic), whilefor the $\pi_{2}$ orbital, they were found to be $9.87 \mathrm{eV}$ (vertical) and $9.79 \mathrm{eV}$ (adiabatic). ${ }^{46}$ Our calculations predict $10.07 \mathrm{eV}$ (vertical) and $9.81 \mathrm{eV}$ (adiabatic) for $\mathrm{n}_{0}$ orbital, and $9.98 \mathrm{eV}$ (vertical) and $9.84 \mathrm{eV}$ (adiabatic) for $\pi_{2}$ orbital. The 
ionization energy measured ina prior electron impact ionization study ${ }^{47}$ provided values of $9.45 \mathrm{eV}$ and $10.0 \mathrm{eV}$ for $\mathrm{DMF}$ and $\mathrm{NMF}$, respectively, which both lie between the vertical ionization energies of the $\mathrm{n}_{0}$ and $\pi_{2}$ orbitals. Baldwin et al.argued that the deviation of the measured threshold with the $\mathrm{n}_{0}$ and $\pi_{2}$ orbital energies isbecause the measured electron ionization energy is actually the weighted average of two ionization values. ${ }^{47}$ In the currentexperiment, the electron impact ionization energy for DMF is9.57 $\pm 0.1 \mathrm{eV}$, which is approximately the meanvalue ofthe vertical ionization energies of the $\mathrm{n}_{0}$ and $\pi_{2}$ orbitals. For NMF, the AE is9.81 $\pm 0.1 \mathrm{eV}$, which is closer tothe computed $\pi_{2}$ orbital ionization energy of $9.87 \mathrm{eV}$ than that ofthe $\mathrm{n}_{0}$ orbital.
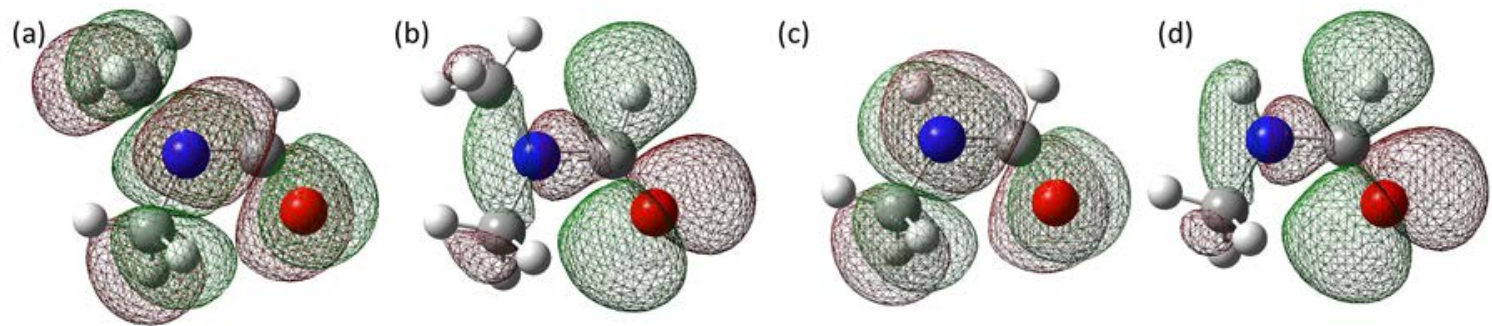

FIG. 5. Tow highest occupied orbitals of DMF and NMF. (a) $\pi_{2}$ orbital of DMF; (b) $n_{0}$ orbital of DMF; (c) $\pi_{2}$ orbital of NMF; (b) $\mathbf{n}_{0}$ orbital of NMF.

\subsection{H atom loss}
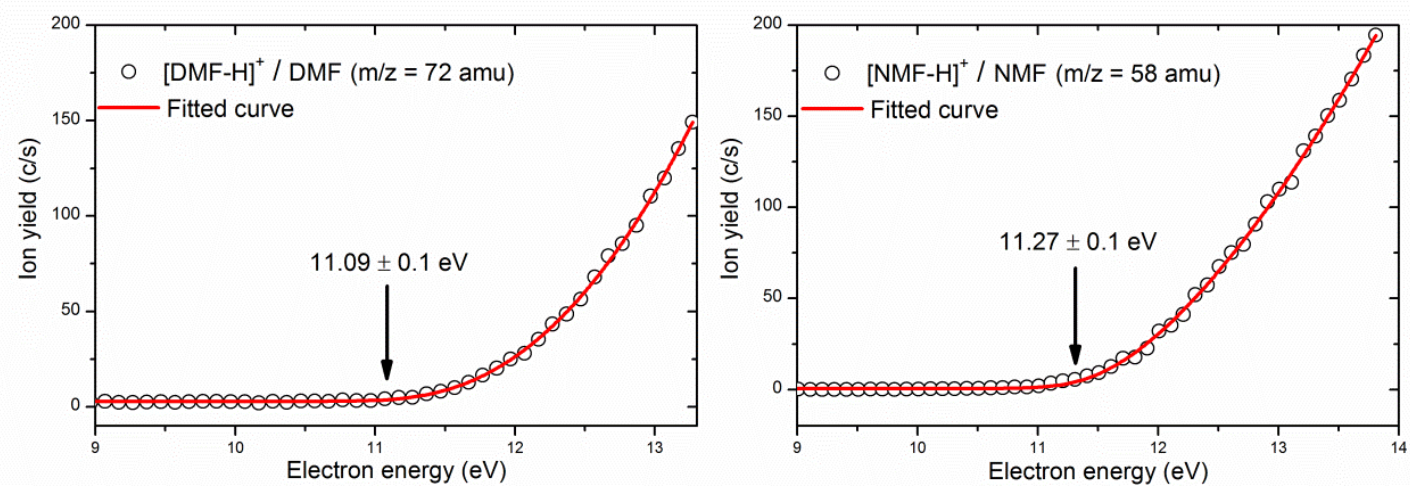

FIG. 6. Ion efficiency curves for the 72 amu ([DMF-H] $]^{+}$) cation from DMF (left) and the 58 amu ([NMF-H $]^{+}$) cation from NMF (right).

For $[\mathrm{DMF}-\mathrm{H}]^{+}$and $[\mathrm{NMF}-\mathrm{H}]^{+}$, theAEsare $11.09 \pm 0.1 \mathrm{eV}$ and $11.27 \pm 0.1 \mathrm{eV}$ (Figure 6), respectively.This result deviates fromthe values obtained in Loudon and Webb's studywhich showed that the $\mathrm{AE}$ of $[\mathrm{DMF}-\mathrm{H}]^{+}(11.35 \mathrm{eV})$ is slightly higher than that of $[\mathrm{NMF}-\mathrm{H}]^{+}$ $(11.20 \mathrm{eV}) .{ }^{29}$ Because our calculation suggests that the $\Delta H^{0}$ for forming [DMF-H] ${ }^{+}$is lower than for $[\mathrm{NMF}-\mathrm{H}]^{+}$, as seen in Tables I and II, the AEs measured in this work should be more reliable.For NMF hydrogen loss can occur at three different sites: from the carbonyl, from the methyl group,or from thenitrogen. The $\Delta H^{0} \mathrm{~s}$ for these three reaction pathways are calculated as $11.07 \mathrm{eV}, 11.21 \mathrm{eV}$ and $14.70 \mathrm{eV}$ respectively.Thus, hydrogen loss from the nitrogen site can be excluded since the $\Delta H^{0}$ of this pathway is more than $3 \mathrm{eV}$ higher than the measured AE. Additionally, since in the mass spectrum of $d_{3} \mathrm{NMF}$ the signal at $61 \mathrm{amu}\left(\left[\mathrm{d}_{3} \mathrm{NMF}-\mathrm{H}\right]^{-}\right)$is much 
more prominent than that at $60 \mathrm{amu}\left(\left[\mathrm{d}_{3} \mathrm{NMF}-\mathrm{D}\right]^{-}\right)$,we conclude that $[\mathrm{NMF}-\mathrm{H}]^{+}$is primarily formed from the loss of a hydrogen on the carbonyl. The estimated enthalpy of reaction $(11.07 \mathrm{eV})$ for this reaction pathway is the lowest amongstthe three reactions mentioned.For DMF hydrogen loss can happen either fromthe carbonyl site or the methyl group with very similar computed $\Delta H^{0} \mathrm{~s}, 10.73 \mathrm{eV}$ and $10.76 \mathrm{eV}$, respectively. However, the mass spectra of isotopically labeled DMFsshow that hydrogen loss from the carbonyl ([ $\left.\mathrm{d}_{1} \mathrm{DMF}-\mathrm{D}\right]^{-}$from $\mathrm{d}_{1} \mathrm{DMF}$, $\left[\mathrm{d}_{6} \mathrm{DMF}-\mathrm{H}\right]^{-}$from $\left.\mathrm{d}_{6} \mathrm{DMF}\right)$ is the more prominent than the hydrogen loss from methyl group ( $\left[\mathrm{d}_{1} \mathrm{DMF}-\mathrm{H}\right]^{-}$from $\mathrm{d}_{1} \mathrm{DMF},\left[\mathrm{d}_{6} \mathrm{DMF}-\mathrm{D}\right]^{-}$from $\left.\mathrm{d}_{6} \mathrm{DMF}\right)$. Therefore, for both DMF and NMF, the formation of the dehydrogenated cations is primarily due to hydrogen loss from the carbonyl sites.

\section{$3.4 \mathrm{~N}-\mathrm{CH}_{3}$ bond cleavage}
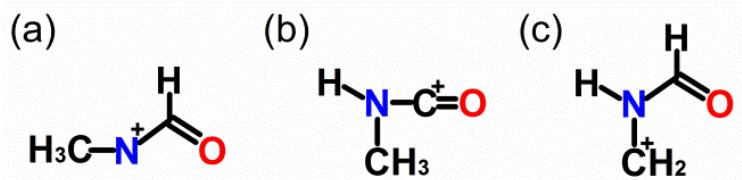

FIG. 7. Isomers of $\mathrm{C}_{2} \mathrm{H}_{4} \mathrm{NO}^{+}$: (a) formed by losing a methyl group from the nitrogen site with no hydrogen transfer, (b) hydrogen transfer from the carbonyl site to the nitrogen, (c) hydrogen transfer from the other methyl group to the nitrogen.

$\mathrm{N}-\mathrm{CH}_{3}$ bond cleavage in DMF is indicated by the peak at $58 \mathrm{amu}\left(\mathrm{C}_{2} \mathrm{H}_{4} \mathrm{NO}^{+}\right)$in the DMF mass spectrum. The fragmentation process resulting inthis cation is provided below.

$$
\mathrm{DMF}+e^{-} \rightarrow \mathrm{C}_{2} \mathrm{H}_{4} \mathrm{NO}^{+}+\mathrm{CH}_{3}+2 e^{-}
$$

Considering the simplest case of $\mathrm{N}-\mathrm{CH}_{3}$ bond cleavage, the cation, $\mathrm{C}_{2} \mathrm{H}_{4} \mathrm{NO}^{+}$, should be in the conformation shown in Figure 7(a). The calculated reaction enthalpy is $13.95 \mathrm{eV}$, which is approximately $3 \mathrm{eV}$ higher than the observedAE value of $10.98 \pm 0.2 \mathrm{eV}$ (Figure 8). Thus, to explain the $\mathrm{AE}$ value for $\mathrm{ONC}_{2} \mathrm{H}_{4}{ }^{+}$, a more complicated reaction mechanism must be involved. If hydrogen rearrangement is allowed for $\mathrm{C}_{2} \mathrm{H}_{4} \mathrm{NO}^{+}$, there can be three isomers, $\mathrm{HCONCH}_{3}{ }^{+}$, $\mathrm{OCNHCH}_{3}{ }^{+}$, and $\mathrm{HCONHCH}_{2}{ }^{+}$, as shown as Figure 7(a)-(c). For isomers (b) and (c) in Figure7, the reaction enthalpies calculated are $10.32 \mathrm{eV}$ and $10.46 \mathrm{eV}$, respectively, which are both slightly lower than the measured AE value. Thus, the breaking ofthe $\mathrm{N}-\mathrm{CH}_{3}$ bond proceeds along with the transfer of a hydrogen atom from the carbonyl or methyl group. In contrast to DMF, in the mass spectrum of NMF, [NMF- $\left.\mathrm{CH}_{3}\right]^{+}$(44 amu) was not observed. 


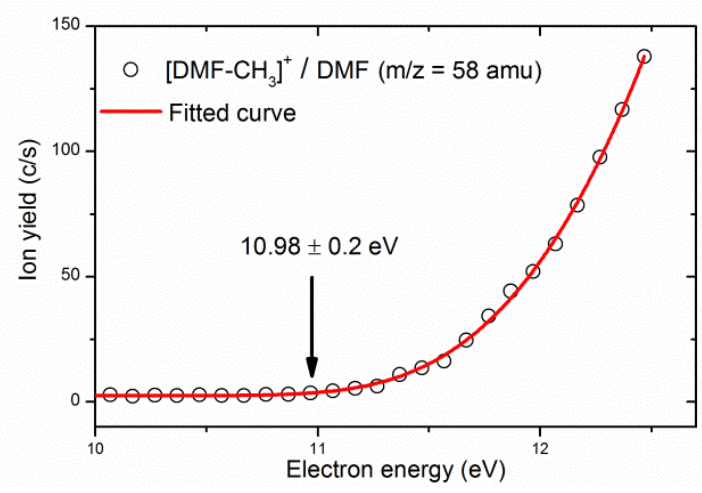

FIG. 8. Ion efficiency curve for the 58 amu $\left(\mathrm{C}_{2} \mathrm{H}_{4} \mathrm{NO}^{+}\right)$cation from DMF.
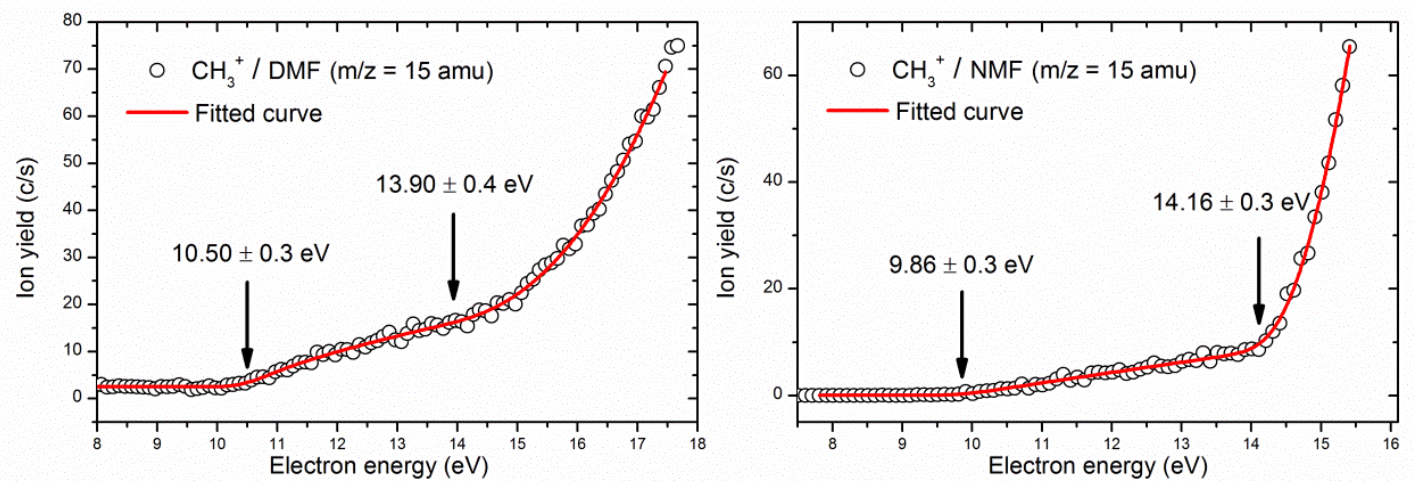

FIG. 9. Ion efficiency curves for the $15 \mathrm{amu}\left(\mathrm{CH}_{3}{ }^{+}\right)$cation from DMF (left) and NMF (right).

$\mathrm{CH}_{3}{ }^{+}$was observed in both the DMF and NMF electron impact spectra. Interestingly, in both cases the ion efficiency curves of $\mathrm{CH}_{3}{ }^{+}$from DMF and NMF show two thresholds. The lower thresholds forCH${ }_{3}^{+}$from DMF and $\mathrm{NMF}$ are $10.50 \pm 0.3 \mathrm{eV}$ and $9.86 \pm 0.3 \mathrm{eV}$ (Figure 9), respectively, which are much lower than the formation enthalpies of $\mathrm{CH}_{3}{ }^{+}(13.82 \mathrm{eV}$ and $14.14 \mathrm{eV}$ ) from the fragmentation of DMF and NMF, respectively. These two values match much better with the ionization energy of the $\mathrm{CH}_{3}$ radical $\left(9.84 \pm 0.05 \mathrm{eV}^{45}\right)$.Thus, in the region below the second threshold, the $\mathrm{CH}_{3}{ }^{+}$does not come from the target molecule but from the ionization of the $\mathrm{CH}_{3}$ radical,a secondary product ofthe electron-molecule interaction. $\mathrm{CH}_{3}$ radicals can be from either simply $\mathrm{N}-\mathrm{CH}_{3}$ bond scission orionizing fragmentation upon electronscattering. Although, as seen in Table $\mathrm{I}, \mathrm{CH}_{3}$ is the most abundant byproduct for the ionizing fragmentation of DMF, this does not apply to NMF. As seen in Table II, $\mathrm{CH}_{3}$ is not a byproduct in the ionizing fragmentation of NMF. Therefore, it is more plausible the $\mathrm{CH}_{3}$ radicals observed are results of electron induced $\mathrm{N}-\mathrm{CH}_{3}$ bond scission in DMF and NFM. In addition, the energies required for $\mathrm{N}-\mathrm{CH}_{3}$ bond scission in DMF and NMF calculated with W1BD procedure are 4.0 $\mathrm{eV}$ and $4.3 \mathrm{eV}$, below the ionizing threshold of $\mathrm{CH}_{3}$ by far, while the ionizing fragmentation for both moleculesstarts at around $10 \mathrm{eV}$. In this way, in the region around $10 \mathrm{eV}$, the $\mathrm{CH}_{3}$ radical yield due to $\mathrm{N}_{-} \mathrm{CH}_{3}$ scission is much more abundant than ionizing fragmentation.Due to the relatively low abundancy of $\mathrm{CH}_{3}$, compared with the DMF and $\mathrm{NMF}$, the intensity of the signal is very low after the first threshold. The second (higher) thresholds for DMF and NMF are $13.90 \pm 0.4 \mathrm{eV}$ and $14.16 \pm 0.3 \mathrm{eV}$, respectively, which bothagree well withthe 
formationenthalpies of $\mathrm{CH}_{3}{ }^{+}$fromdirect electron-induced fragmentation of DMF $(13.82 \mathrm{eV})$ and NMF (14.14 eV), as shown in Tables I and II.

\section{5 $\mathrm{C}_{2} \mathrm{H}_{6} \mathrm{~N}^{+}$(44 amu) from DMF and its further decay products: $\mathrm{C}_{2} \mathrm{H}_{5} \mathrm{~N}^{+}$(43 amu), $\mathrm{C}_{2} \mathrm{H}_{4} \mathrm{~N}^{+}$(42 amu), $\mathrm{NH}_{4}^{+}$(18 amu)}

The workby Loudon and $\mathrm{Webb}^{29}$ suggests that, because the AE value is approximately $1.3 \mathrm{eV}$ smaller than the predicted $\Delta \mathrm{H}^{0}$ value for $\mathrm{N}\left(\mathrm{CH}_{3}\right)_{2}{ }^{+}$, thecation, $\mathrm{C}_{2} \mathrm{H}_{6} \mathrm{~N}^{+}$, detected in the electron impact fragmentation of methylated formamide should be due to the isomer, $\mathrm{NHCH}_{2} \mathrm{CH}_{3}{ }^{+}$, as shownin Figure10.

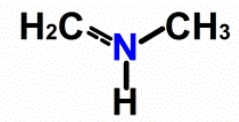

FIG. 10. Structure of $\mathrm{NHCH}_{2} \mathrm{CH}_{3}{ }^{+}$.

They further suggested that the $(\mathrm{C}=\mathrm{O})-\mathrm{N}$ bond cleavage is followed by hydrogentransfer from the carbon to the nitrogen site, which is stabilized by the formation of a partial double $\mathrm{N}=\mathrm{CH}_{2}$ bond. The isotopic study in this work provides direct support for this postulate. Additionally,our isotopic mass spectra confirm that $\mathrm{C}-\mathrm{H}$ bond cleavage during this process primarily originates from the carbonyl site $((\mathrm{C}=\mathrm{O})-\mathrm{H})$ rather than from the $\mathrm{CH}_{3}$ group. The most intense peak at44 amu $\left(\mathrm{C}_{2} \mathrm{H}_{6} \mathrm{~N}^{+}\right)$is shifted to $45 \mathrm{amu}\left(\mathrm{C}_{2} \mathrm{H}_{5} \mathrm{DN}^{+}\right)$in the $\mathrm{d}_{1} \mathrm{DMF}$ mass spectra and to $49 \mathrm{amu}\left(\mathrm{C}_{2} \mathrm{HD}_{5} \mathrm{~N}^{+}\right)$in the $\mathrm{d}_{6} \mathrm{DMF}$ spectra.This can only be explained as follows: the $\mathrm{H} / \mathrm{D}$ atom on the carbonyl site is transferred to nitrogen as the amide bond breaks. The AE for $\mathrm{C}_{2} \mathrm{H}_{6} \mathrm{~N}^{+}$from DMF is $10.71 \pm 0.1 \mathrm{eV}$, which is lower than the reported value $11.60 \mathrm{eV},{ }^{29}$ but wellmatches the calculated enthalpy of reaction of $10.48 \mathrm{eV}$, asshown in reaction (2), in which $\mathrm{CO}$ and $\mathrm{H}$ are the byproducts. The reaction enthalpyforthe other possible pathway, which isshown in reaction (3) andleads to the isomer $\mathrm{CH}_{3} \mathrm{NHCH}_{2}{ }^{+}$, was also calculated. The $\Delta H^{0}$ of $9.80 \mathrm{eV}$ is approximately $1 \mathrm{eV}$ lower than the $\mathrm{AE}$ for $\mathrm{C}_{2} \mathrm{H}_{6} \mathrm{~N}^{+}$. The neutral product,HCO, is not likely to form along with $\mathrm{CH}_{3} \mathrm{NHCH}_{2}{ }^{+}$, supporting the postulatethat the hydrogen transfers from the carbonyl group to the nitrogen site to produce the $\mathrm{CH}_{3} \mathrm{NHCH}_{2}{ }^{+}$isomer.

$$
\begin{array}{ll}
\mathrm{DMF}+e^{-} \rightarrow \mathrm{CH}_{3} \mathrm{NHCH}_{2}^{+}+\mathrm{H}+\mathrm{CO}+2 e^{-} & \Delta H^{0}=10.48 \mathrm{eV} \\
\mathrm{DMF}+e^{-} \rightarrow \mathrm{CH}_{3} \mathrm{NHCH}_{2}^{+}+\mathrm{HCO}+2 e^{-} & \Delta H^{0}=9.80 \mathrm{eV}(3)
\end{array}
$$

$\mathrm{C}_{2} \mathrm{H}_{6} \mathrm{~N}^{+}$can further dissociate into $\mathrm{C}_{2} \mathrm{H}_{5} \mathrm{~N}^{+}$or $\mathrm{C}_{2} \mathrm{H}_{4} \mathrm{~N}^{+}$by losing a hydrogen atom or $\mathrm{H}_{2}$, respectively. ${ }^{28}$ In the mass spectrum of DMF, there are peaks at $43 \mathrm{amu}$ and $42 \mathrm{amu}$. The peak at $42 \mathrm{amu}\left(\mathrm{C}_{2} \mathrm{H}_{4} \mathrm{~N}^{+}\right)$is at a much higher intensity than the peak at $43 \mathrm{amu}$; thus, $\mathrm{C}_{2} \mathrm{H}_{6} \mathrm{~N}^{+}$is much more likely to decay by losing $\mathrm{H}_{2}$ than a hydrogen atom. The two AEs for $43 \mathrm{amu}$ are $10.20 \pm 0.1 \mathrm{eV}$ and $16.37 \pm 0.2 \mathrm{eV}$, as shown in Figure11. The first threshold at $10.20 \mathrm{eV}$ represents $\mathrm{C}_{2} \mathrm{H}_{5} \mathrm{~N}^{+}$because the enthalpies of reaction for all the possible pathways that form $\mathrm{HCON}^{+}$are higher than this value. The values for the reaction enthalpies that forms the isomers, $\mathrm{NCH}_{2} \mathrm{CH}_{3}{ }^{+}$and $\mathrm{NHCH}_{2} \mathrm{CH}_{2}{ }^{+}$, are $10.85 \mathrm{eV}$ (reaction (4)) and $10.09 \mathrm{eV}$ (reaction (5)), 
respectively. Because $\Delta H^{0}$ is still higher than the $\mathrm{AE}$ value, $\mathrm{C}_{2} \mathrm{H}_{5} \mathrm{~N}^{+}$is more likely to have the structure $\mathrm{NHCH}_{2} \mathrm{CH}_{2}^{+}$.

$$
\begin{array}{lc}
\mathrm{DMF}+e^{-} \rightarrow \mathrm{NCH}_{2} \mathrm{CH}_{3}{ }^{+}+\mathrm{CO}+\mathrm{H}_{2}+2 e^{-} & \multicolumn{2}{c}{\Delta H^{0}=10.85 \mathrm{eV}} \\
\mathrm{DMF}+e^{-} \rightarrow \mathrm{NHCH}_{2} \mathrm{CH}_{2}+\mathrm{CO}+\mathrm{H}_{2}+2 e^{-} & \Delta H^{0}=10.09 \mathrm{eV}
\end{array}
$$

The second threshold of $43 \mathrm{amu}$ from DMF at $16.37 \mathrm{eV}$ should represent $\mathrm{HCON}^{+}$or $\mathrm{CONH}^{+}$and reactions (6)-(9) are possible fragmentation pathways. Among these fragmentation pathways, reaction (8) is most likely because its enthalpy of reaction is most similar to the detected $\mathrm{AE}$ value. The deviation between the calculated $\Delta \mathrm{H}^{0}$ and the $\mathrm{AE}$ value should be owing to the fact that the reaction (8) involves multiple bond dissociation and hydrogen atom transfer; thus, it is very likely that some transient states increase the energy threshold for the reaction to proceed.

$$
\begin{array}{ll}
\mathrm{DMF}+e^{-} \rightarrow \mathrm{HCON}^{+}+2 \mathrm{CH}_{3}+2 e^{-} & \Delta H^{0}=18.10 \mathrm{eV} \\
\mathrm{DMF}+e^{-} \rightarrow \mathrm{HCON}^{+}+\mathrm{C}_{2} \mathrm{H}_{6}+2 e^{-} & \Delta H^{0}=14.18 \mathrm{eV} \\
\mathrm{DMF}+e^{-} \rightarrow \mathrm{CONH}^{+}+2 \mathrm{CH}_{3}+2 e^{-} & \Delta H^{0}=15.68 \mathrm{eV} \\
\mathrm{DMF}+e^{-} \rightarrow \mathrm{CONH}^{+}+\mathrm{C}_{2} \mathrm{H}_{6}+2 e^{-} & \Delta H^{0}=11.76 \mathrm{eV}
\end{array}
$$



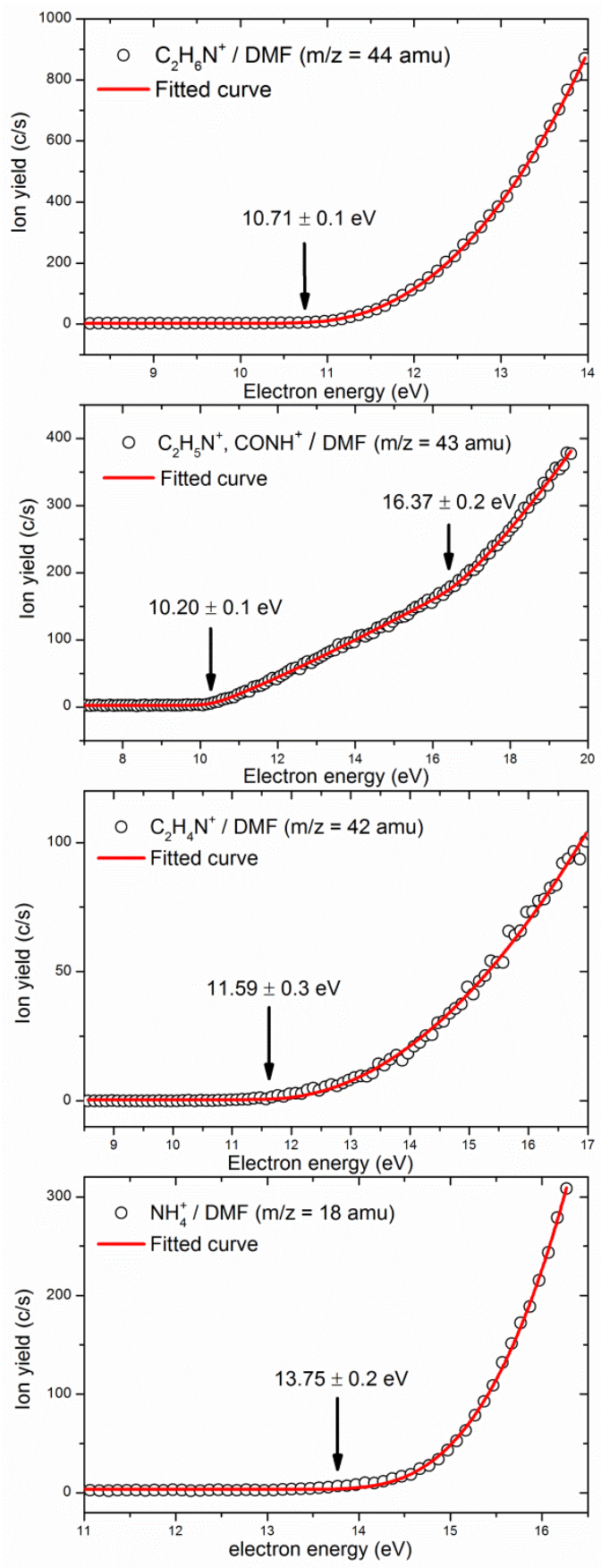

FIG. 11. From top to bottom, ion efficiency curves from DMF at $44 \mathrm{amu}\left(\mathrm{C}_{2} \mathrm{H}_{6} \mathrm{~N}^{+}\right), 43 \mathrm{amu}\left(\mathrm{C}_{2} \mathrm{H}_{5} \mathrm{~N}^{+} / \mathrm{CONH}^{+}\right), 42 \mathrm{amu}$ $\left(\mathrm{C}_{2} \mathrm{H}_{4} \mathrm{~N}^{+}\right)$, and 18 amu $\left(\mathrm{NH}_{4}{ }^{+}\right)$.

The peak at 42 amu in the mass spectrum of DMFoccurs at amuch higher intensity than that at $43 \mathrm{amu}$. As discussed above,this peak is due to $\mathrm{C}_{2} \mathrm{H}_{4} \mathrm{~N}^{+}$. The $\mathrm{AE}$ of the mass 42 was determined to be $11.59 \pm 0.3 \mathrm{eV}$. The calculated $\Delta H^{0}$ of $\mathrm{OCN}^{+}$is at least $17.32 \mathrm{eV}$, which is almost $6 \mathrm{eV}$ higher than the observed value. This further supports our identification of mass 42 as $\mathrm{C}_{2} \mathrm{H}_{4} \mathrm{~N}^{+}$. The $\Delta H^{0}$ of the following two isomersN $\left(\mathrm{CH}_{2}\right)_{2}{ }^{+}$and $\mathrm{NHCHCH}_{2}{ }^{+}$were estimated to 
be $11.72 \mathrm{eV}$ and $12.80 \mathrm{eV}$, respectively. Thus, $\mathrm{C}_{2} \mathrm{H}_{4} \mathrm{~N}^{+}$has the structure $\mathrm{N}\left(\mathrm{CH}_{2}\right)_{2}{ }^{+}$. This is also consistent with our study with isotopically-labeled DMF in which a major peak was observedat $42 \mathrm{amu}\left(\mathrm{N}\left(\mathrm{CH}_{2}\right)_{2}{ }^{+}\right)$from $\mathrm{d}_{1} \mathrm{DMF}$ and at $44 \mathrm{amu}\left(\mathrm{N}\left(\mathrm{CD}_{2}\right)_{2}{ }^{+}\right)$from $\mathrm{d}_{6} \mathrm{DMF}$.

$$
\begin{array}{ll}
\mathrm{DMF}+e^{-} \rightarrow \mathrm{N}\left(\mathrm{CH}_{2}\right)_{2}{ }^{+}+\mathrm{HCO}+\mathrm{H}_{2}+2 e^{-} & \Delta H^{0}=11.72 \mathrm{eV} \\
\mathrm{DMF}+e^{-} \rightarrow \mathrm{NHCHCH}_{2}{ }^{+}+\mathrm{HCO}+\mathrm{H}_{2}+2 e^{-} & \Delta H^{0}=12.80 \mathrm{eV}
\end{array}
$$

In a study by Levsen and McLafferty, ${ }^{28} \mathrm{C}_{2} \mathrm{H}_{6} \mathrm{~N}^{+}$was also shown to decay to $\mathrm{NH}_{4}{ }^{+}$by losing $\mathrm{C}_{2} \mathrm{H}_{2}$. Such a reaction pathway explains the $18 \mathrm{amu}$ peak in our mass spectra. The $\mathrm{AE}$ of $\mathrm{NH}_{4}{ }^{+}$ was determined to be $13.75 \pm 0.2 \mathrm{eV}$. From the enthalpies of reaction, all of the following three pathways, reaction (12-14), can contribute to the formation of the $\mathrm{NH}_{4}{ }^{+}$ion. However, the $\Delta \mathrm{H}^{0}$ of reaction (12) is closest tothe experimentally determined $\mathrm{AE}$. Thus, it is reasonable to conclude that the pathway shown as reaction (12) is the most probable. However, $\mathrm{CO}$ and $\mathrm{H}$ are the most likely byproducts released when $\mathrm{C}_{2} \mathrm{H}_{6} \mathrm{~N}^{+}$is formed; thus, reaction (12) can be interpreted as reaction (2) followed by $\mathrm{C}_{2} \mathrm{H}_{6} \mathrm{~N}^{+}$losing $\mathrm{C}_{2} \mathrm{H}_{2}$, which further justifies the postulationthat $\mathrm{NH}_{4}{ }^{+}$ decays from $\mathrm{C}_{2} \mathrm{H}_{6} \mathrm{~N}^{+}{ }^{28}$

$$
\begin{array}{lr}
\mathrm{DMF}+e^{-} \rightarrow \mathrm{NH}_{4}{ }^{+}+\mathrm{C}_{2} \mathrm{H}_{2}+\mathrm{CO}+\mathrm{H}+2 e^{-} & \Delta H^{0}=12.05 \mathrm{eV}(12) \\
\mathrm{DMF}+e^{-} \rightarrow \mathrm{NH}_{4}{ }^{+}+\mathrm{C}_{2} \mathrm{H}_{2}+\mathrm{HCO}+2 e^{-} & \Delta H^{0}=11.36 \mathrm{eV}(13) \\
\mathrm{DMF}+e^{-} \rightarrow \mathrm{NH}_{4}{ }^{+}+\mathrm{C}_{2} \mathrm{H}_{3}+\mathrm{CO}+2 e^{-} & \Delta H^{0}=10.64 \mathrm{eV}(14)
\end{array}
$$

\section{6 $\mathrm{CH}_{4} \mathrm{~N}^{+}(30 \mathrm{amu})$ and its further decay products: $\mathrm{CH}_{3} \mathrm{~N}^{+}(29 \mathrm{amu})$ and $\mathrm{CH}_{2} \mathrm{~N}^{+}$ (28 amu)}

The peak representing $\mathrm{CH}_{4} \mathrm{~N}^{+}$(30 amu) is prominent in both the mass spectra of DMF and $\mathrm{NMF}$ with the $\mathrm{AE}$ values at $12.08 \pm 0.2 \mathrm{eV}$ and $10.06 \pm 0.1 \mathrm{eV}$ (Figure 12), respectively. The cleavage of $(\mathrm{C}=\mathrm{O})-\mathrm{N}$ bond in $\mathrm{NMF}$ to form $\mathrm{NHCH}_{3}{ }^{+}$, shown as reaction (15), requires a reaction enthalpy of $14.10 \mathrm{eV}$ which is around $4 \mathrm{eV}$ higher than the measured $\mathrm{AE}$ value $(10.06 \pm 0.1 \mathrm{eV})$. Thus, this reaction pathway can be excluded. As suggested in reference [29], $\mathrm{NH}_{2} \mathrm{CH}_{2}{ }^{+}$should be the stable isomer of $\mathrm{CH}_{4} \mathrm{~N}^{+}$rather than $\mathrm{NHCH}_{3}{ }^{+}$. Measurement of $\mathrm{AE}$ for $\mathrm{CH}_{4} \mathrm{~N}^{+}$from NMF in this work supports this point. The enthalpies for forming $\mathrm{NH}_{2} \mathrm{CH}_{2}{ }^{+}$from NMF, seen in reaction (16), (17), match much better with the $\mathrm{AE} 10.06 \pm 0.1 \mathrm{eV}$. The fact that the $\mathrm{AE}$ for $\mathrm{CH}_{4} \mathrm{~N}^{+}$from NMF is closer to the $\Delta \mathrm{H}^{0}$ of reaction (16) indicates that $\mathrm{HCO}$ is the byproduct. Thus, when the amide bond $((\mathrm{C}=\mathrm{O})-\mathrm{N})$ dissociates, in the case of NMF, a hydrogen atom can transfer from either the carbonyl site or the methyl group to the nitrogen site. This is different from the case of amide bond cleavage in DMF in which the hydrogen transfer from the carbonyl group to the nitrogen occurs simultaneously with amide bond cleavage. Thus, DMF fragments into the cation, $\mathrm{C}_{2} \mathrm{H}_{6} \mathrm{~N}^{+}$, and the other byproducts of $\mathrm{CO}$ and $\mathrm{H}$, rather than $\mathrm{HCO}$ as the byproduct. This postulateis also supported by the huge difference of the intensity ratio of mass $32 \mathrm{amu}\left(\mathrm{CD}_{2} \mathrm{H}_{2} \mathrm{~N}^{+}\right)$to $33 \mathrm{amu}$ $\left(\mathrm{CD}_{3} \mathrm{HN}^{+}\right)$in the $\mathrm{d}_{3} \mathrm{NMF}$ mass spectrum and mass $49 \mathrm{amu}\left(\mathrm{C}_{2} \mathrm{D}_{5} \mathrm{HN}^{+}\right)$to 50 amu $\left(\mathrm{C}_{2} \mathrm{D}_{6} \mathrm{~N}^{+}\right)$in the $\mathrm{d}_{6} \mathrm{DMF}$ mass spectrum. In the $\mathrm{d}_{3} \mathrm{NMF}$ mass spectrum, $33 \mathrm{amu}\left(\mathrm{CD}_{3} \mathrm{HN}^{+}\right)$is approximately half 
of the height of $32 \mathrm{amu}\left(\mathrm{CD}_{2} \mathrm{H}_{2} \mathrm{~N}^{+}\right)$, whereas in the $\mathrm{d}_{6} \mathrm{DMF}$ mass spectrum, $50 \mathrm{amu}\left(\mathrm{C}_{2} \mathrm{D}_{6} \mathrm{~N}^{+}\right)$is at least one order of magnitude lower than $49 \mathrm{amu}\left(\mathrm{C}_{2} \mathrm{D}_{5} \mathrm{HN}^{+}\right)$and is almost invisible.
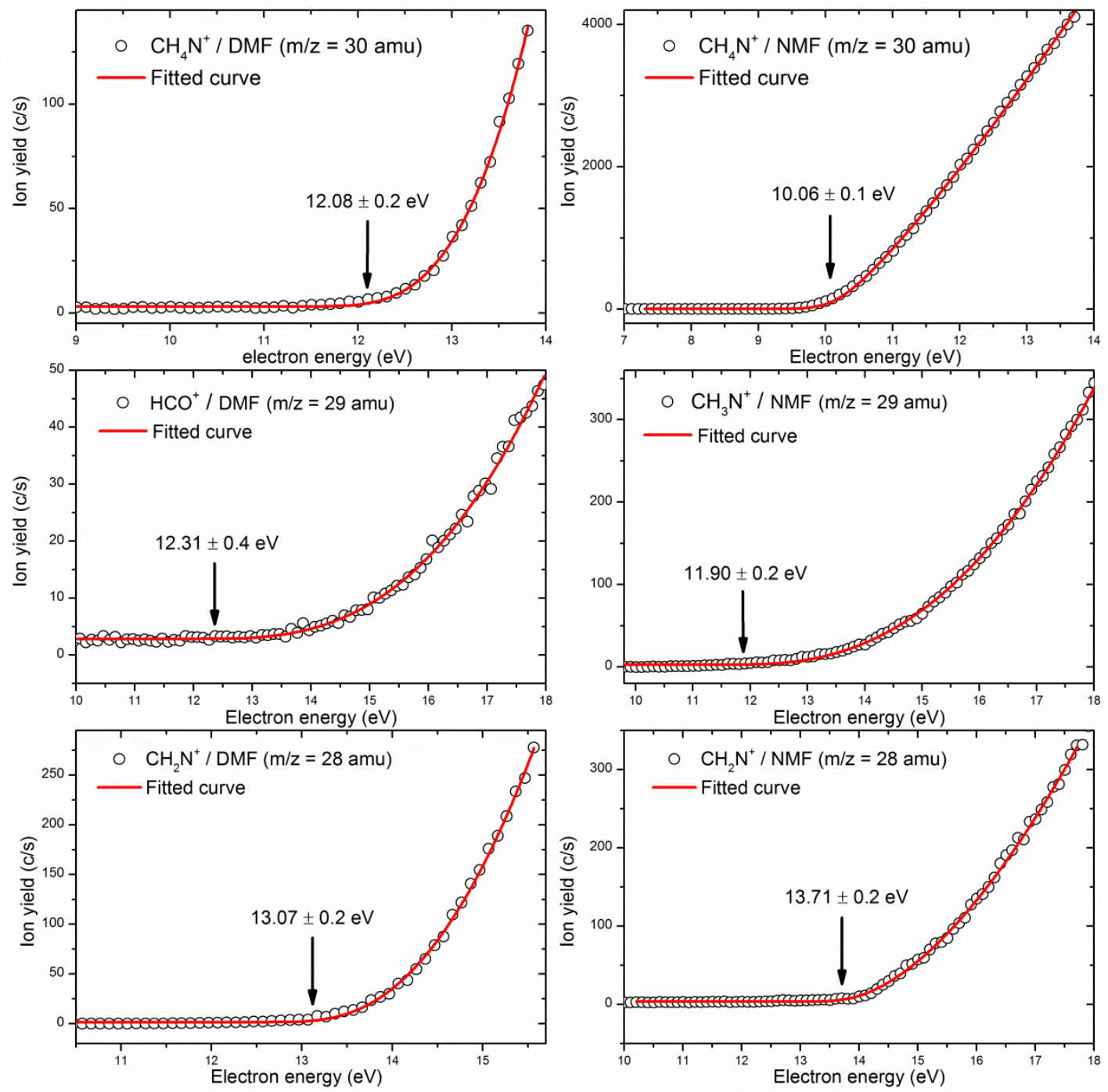

FIG. 12. From top to bottom, ion efficiency curves for the $30 \mathrm{amu}\left(\mathrm{CH}_{4} \mathrm{~N}^{+}\right), 29 \mathrm{amu}$ (left, $\mathrm{HCO}^{+}$, right, $\left.\mathrm{CH}_{3} \mathrm{~N}^{+}\right)$, and $28 \mathrm{amu}$ $\left(\mathrm{CH}_{2} \mathrm{~N}^{+}\right)$cations. Right column shows cations from DMF; left column shows cations from NMF.

$$
\begin{array}{lc}
\mathrm{NMF}+e^{-} \rightarrow \mathrm{NHCH}_{3}{ }^{+}+\mathrm{HCO}+2 e^{-} & \Delta H^{0}=14.10 \mathrm{eV} \\
\mathrm{NMF}+e^{-} \rightarrow \mathrm{NH}_{2} \mathrm{CH}_{2}{ }^{+}+\mathrm{HCO}+2 e^{-} & \Delta H^{0}=10.22 \mathrm{eV} \\
\mathrm{NMF}+e^{-} \rightarrow \mathrm{NH}_{2} \mathrm{CH}_{2}{ }^{+}+\mathrm{CO}+\mathrm{H}+2 e^{-} & \Delta H^{0}=10.90 \mathrm{eV}
\end{array}
$$

The $\mathrm{AE}$ value for $\mathrm{CH}_{4} \mathrm{~N}^{+}$from DMF is $12.08 \pm 0.2 \mathrm{eV}$, which is approximately $2 \mathrm{eV}$ lower than the formation heat of the isomer, $\mathrm{NHCH}_{3}{ }^{+}(14.04 \mathrm{eV})$, suggests that hydrogen transfer must also be involved in thisfragmentation pathway. Meanwhile, the formation heat of the isomer, $\mathrm{NH}_{2} \mathrm{CH}_{2}{ }^{+}$, is only $10.16 \mathrm{eV}$, as shown in TableI. Thus, $\mathrm{NH}_{2} \mathrm{CH}_{2}{ }^{+}$is more likely to represent the 
cation at $30 \mathrm{amu}$. The reason the detected threshold is higher than the calculation may be because the reaction to form $\mathrm{NH}_{2} \mathrm{CH}_{2}{ }^{+}$consists of two steps: 1) the breaking of the $\mathrm{N}-\mathrm{CH}_{3}$ bond and the rearrangement of one hydrogen atom(the threshold for this step, as discussed above, is approximately $11 \mathrm{eV})$, and 2) the breaking of the $(\mathrm{C}=\mathrm{O})-\mathrm{N}$ bond and the transfer of another hydrogen atom to the nitrogen site further increases the threshold to approximately $12 \mathrm{eV}$.

$\mathrm{CH}_{4} \mathrm{~N}^{+}$can decay by losing a hydrogen atom or $\mathrm{H}_{2}(30 \mathrm{amu} \rightarrow 29 \mathrm{amu}$ or $28 \mathrm{amu}) .{ }^{29} \mathrm{In} \mathrm{NMF}$, the $\mathrm{AE}$ values of mass $29 \mathrm{amu}$ and 28 amuwere determined to be $11.90 \pm 0.2 \mathrm{eV}$ and $13.71 \pm 0.2 \mathrm{eV}$, respectively. The computed formation enthalpies of $\mathrm{HCO}^{+}(12.42 \mathrm{eVand}$ $12.11 \mathrm{eV})$ are higher than the $\mathrm{AE}$ for the $29 \mathrm{amu}$ cation $(11.90 \pm 0.2 \mathrm{eV})$, as shown in Table II. Associating the $\mathrm{AE}$ with the formation of $\mathrm{NH}_{2} \mathrm{CH}^{+}$or $\mathrm{NHCH}_{2}{ }^{+}$better explains the mechanism because the $\Delta H^{0}$ values for forming these two cations are $11.87 \mathrm{eV}$ and $11.73 \mathrm{eV}$, which are slightly lower than $11.90 \pm 0.2 \mathrm{eV}$. For mass 28 , again the calculation suggests that $\mathrm{CO}^{+}$requires a higher $\mathrm{AE}$ value of at least $14.83 \mathrm{eV}$. Thus, the experimental $\mathrm{AE}$ value is due to the formation of $\mathrm{CH}_{2} \mathrm{~N}^{+}$rather than $\mathrm{CO}^{+}$. Based on the calculated $\Delta \mathrm{H}^{0} \mathrm{~S}$ of $\mathrm{NCH}_{2}{ }^{+}$(reaction (18)), $\mathrm{NHCH}^{+}$ (reaction (19)), and $\mathrm{NH}_{2} \mathrm{C}^{+}$(reaction (20)), which are $15.38 \mathrm{eV}, 12.29 \mathrm{eV}$, and $14.51 \mathrm{eV}$, respectively, reaction (19) is the only pathway with a $\Delta H^{0}$ that is lower than $13.71 \pm 0.2 \mathrm{eV}$. Thus, the cation at $29 \mathrm{amu}$ represents $\mathrm{NHCH}^{+}$.The slightdisagreement between the $\mathrm{AE}$ value and the theoretical threshold (the $\mathrm{AE}$ is approximately $1.5 \mathrm{eV}$ higher than the $\Delta H^{0}$ ) is explainable because theenthalpy of reaction depends only on the final and initial states and the real determinants of the $\mathrm{AE}$ are the transition states in the pathway, which may be higher than the $\Delta H^{0}$.

$$
\begin{array}{ll}
\mathrm{NMF}+e^{-} \rightarrow \mathrm{NCH}_{2}^{+}+\mathrm{HCO}+\mathrm{H}_{2}+2 e^{-} & \Delta H^{0}=15.38 \mathrm{eV} \\
\mathrm{NMF}+e^{-} \rightarrow \mathrm{NHCH}^{+}+\mathrm{HCO}+\mathrm{H}_{2}+2 e^{-} & \Delta H^{0}=12.29 \mathrm{eV} \\
\mathrm{NMF}+e^{-} \rightarrow \mathrm{NH}_{2} \mathrm{C}^{+}+\mathrm{HCO}+\mathrm{H}_{2}+2 e^{-} & \Delta H^{0}=14.51 \mathrm{eV}
\end{array}
$$

For DMF, the AE values for masses 29 and 28 were determined to be $12.31 \pm 0.4 \mathrm{eV}$ and $13.07 \pm 0.2 \mathrm{eV}$, respectively. As discussed in the section onthe mass spectrum of DMF, the peak at $29 \mathrm{amu}$ isprimarily due toHCO${ }^{+}$, and that at $28 \mathrm{amu}$ is due to both $\mathrm{CO}^{+}$and $\mathrm{CH}_{2} \mathrm{~N}^{+}$. The $\mathrm{AE}$ value of mass 29 agrees with the calculated formation enthalpy value $(12.22 \mathrm{eV})$, considering the fragmentation is a simple bond cleavage, as shown in reaction (21). If hydrogen transfer is allowed, as shown in reaction (22), the formation heat can be even lowered to $12.15 \mathrm{eV}$. Because hydrogen transfer occurs in the formation of $\mathrm{C}_{2} \mathrm{H}_{6} \mathrm{~N}^{+}$as mentioned in the above discussion on amide bond cleavage, it is very likely that this process also occurs when amide bond cleavage results in $\mathrm{HCO}^{+}$. Thus reaction (21), (22) are both possible for forming the 29 amu cation.For the other possibility of $29 \mathrm{amu}$ that represents $\mathrm{CH}_{3} \mathrm{~N}^{+}$, the formation heat is calculated to be lower than $11 \mathrm{eV}$, as shown in Table 1 . Thus, $\mathrm{HCO}^{+}$should be the main component of the peak at 29 amu from DMF.

$$
\mathrm{DMF}+e^{-} \rightarrow \mathrm{HCO}^{+}+\mathrm{N}\left(\mathrm{CH}_{3}\right)_{2}+2 e^{-} \quad \Delta H^{0}=12.22 \mathrm{eV}
$$




$$
\mathrm{DMF}+e^{-} \rightarrow \mathrm{HCO}^{+}+\mathrm{NHCH}_{2} \mathrm{CH}_{3}+2 e^{-} \quad \Delta H^{0}=12.15 \mathrm{eV}
$$

For $28 \mathrm{amu}$, the computed $\Delta H^{0}$ of $\mathrm{CO}^{+}$is $14.71 \mathrm{eV}$, and for $\mathrm{NHCH}^{+}$, depending on the byproducts, the $\Delta H^{0}$ values are $12.23 \mathrm{eV}$ (reaction (23)) and $11.52 \mathrm{eV}$ (reaction (24)), which are lower than the measured $\mathrm{AE}$ value of $13.07 \mathrm{eV}$. As stated in the section on $\mathrm{C}_{2} \mathrm{H}_{6} \mathrm{~N}^{+}$, hydrogen transfer should occur from the carbonyl site. Thus, HCO is not likely to be a byproduct of this reaction. Reaction (23) is the pathway associated with the $\mathrm{AE}$ value, of which $\Delta H^{0}$ is actually closer to the AE value of $13.07 \pm 0.2 \mathrm{eV}$. Similar to the other cases discussed above that involve multiple bond dissociation, the experimental $\mathrm{AE}$ value tends to be somewhat higher than the calculated estimate of the $\Delta H^{0}$.

$$
\begin{aligned}
& \mathrm{DMF}+e^{-} \rightarrow \mathrm{NHCH}^{+}+\mathrm{CO}+\mathrm{CH}_{3}+\mathrm{H}_{2}+2 e^{-} \Delta H^{0}=12.23 \mathrm{eV} \\
& \mathrm{DMF}+e^{-} \rightarrow \mathrm{NHCH}^{+}+\mathrm{HCO}+\mathrm{CH}_{4}+2 e^{-} \quad \Delta H^{0}=11.52 \mathrm{eV}
\end{aligned}
$$

\section{Conclusions}

This work provides a very detailed examination of the cationic mass spectra of DMF and NMF, as well as the deuterated samples, $d_{1} D M F, d_{6} D M F$, and $d_{3} N M F$, obtained from electron impact ionization at $70 \mathrm{eV}$. All of the major cationic fragments fromboth DMF and NMF were carefully identified by comparing them with the mass spectra ofisotopically labelled samples. The ion efficiency curves in the region of $5-20 \mathrm{eV}$ for these cations were measured and reported. By fitting the Wannier cross-section function to the efficiency curves, the AEs for all of the cations were determined. The AEmeasurementsperformed in this work providerevised dataforvalues obtainedin previous studies. ${ }^{48,29}$ In addition, we reportseveral AEs and mass spectra of deuterated DMF and NMFnot previouslydocumented. We also present a detailed analysis of the reaction pathways for the formation of each cation. For example,by comparing with the mass spectra of isotopically-labeled molecules,we confirmed and clarified the hydrogen transfer pathway during the amide bond cleavage. For DMF, the hydrogen atom on the carbonyl site relocates to nitrogen, and for NMF, the hydrogen atom from both the carbonyl site and the methyl group can transfer to thenitrogen. However, transfer from the carbonyl site is preferable.We also discovered that this hydrogen transfer behavior not only occurs when the amide bond breaks but also when the $\mathrm{N}-\mathrm{CH}_{3}$ bond cleaves. The fragmentation patterns of DMF and NMF bear some similarity: amide bond cleavage with hydrogen atom transfer is the most dominant pathway, and the loss of a hydrogen atom primarily occurs fromthe carbonyl site. However, there are differences: the hydrogen relocation has a greater chance oforiginating from a methyl group in the case of NMF than from DMF. Overall,this work provides a very detailed report of the ionization and fragmentation behavior of methylated formamides. The data provided in this paper will contribute broadly to understanding the fragmentation patterns of key biomolecules that are relevant in the astrophysical, prebiotic, and radiological fields. 


\section{Acknowledgements}

This material is based upon work supported by the U.S. Department of Energy Office of Science, Office of Basic Energy Sciences under Award Number DE-FC02-04ER15533. This is contribution number NDRL 5121 from the Notre Dame Radiation Laboratory. We would like to thank John H. Brems and Joanna Kabuye for their lab assistance during this project.

\section{References}

${ }^{1}$ G.R. Adande, N.J. Woolf, and L.M. Ziurys, Astrobiology 13, 439 (2013).

2 B.M. Jones, C.J. Bennett, and R.I. Kaiser, Astrophys. J. 734, 78 (2011).

${ }^{3}$ P. Redondo, C. Barrientos, and A. Largo, Astrophys. J. 793, 32 (2014).

${ }^{4}$ M.M. Dawley, C. Pirim, and T.M. Orlando, J. Phys. Chem. A 118, 1228 (2014).

${ }^{5}$ B. Bhushan, 39th COSPAR Sci. Assem. Held 14-22 July 2012 (2012).

${ }^{6}$ L.L.S. d. Hendecourt, P. de Marcellus, C. Meinert, I. Myrgorodska, L. Nahon, P. Modica, T. Buhse, and U.J. Meierhenrich, IAU Gen. Assem. (2015).

${ }^{7}$ A. Kumar, R. Sharma, and Kamaluddin, Astrobiology 14, 769 (2014).

${ }^{8}$ A. Lopez-Sepulcre, A.A. Jaber, E. Mendoza, B. Lefloch, C. Ceccarelli, C. Vastel, R. Bachiller, J. Cernicharo, C. Codella, C. Kahane, M. Kama, and M. Tafalla, Mon. Not. R. Astron. Soc. 449, 2438 (2015).

9 T.M. Orlando, H. Barks, R. Buckley, G. Grieves, E. Dimauro, and N.V. Hud, Astrobiol. Sci. Conf. 2010 Evol. Life Surviv. Catastrophes Extrem. Earth Beyond (2010).

${ }^{10}$ R. Saladino, C. Crestini, F. Ciciriello, G. Costanzo, R. Negri, and E. di Mauro, Proc. Third Eur. Work. Exo-Astrobiology (2004).

${ }^{11}$ A.M. Schoffstall, Orig. Life 7, 399 (1976).

${ }^{12}$ S.P. Langdon, J.A. Hickman, A. Gescher, M.F. Stevens, D. Chubb, and L.M. Vickers, Eur. J. Cancer Clin. Oncol. 21, 745 (1985).

${ }^{13}$ A. Gescher, N.W. Gibson, J.A. Hickman, S.P. Langdon, D. Ross, and G. Atassi, Br. J. Cancer 45, 843 (1982). 
${ }^{14}$ P.G. Cooksey, E.N. Gate, A. Gescher, J.A. Hickman, S.P. Langdon, and M.F. Stevens, Biochem. Pharmacol. 32, 3037 (1983).

${ }^{15}$ D.L. Dexter, E.S. Lee, S.F. Bliven, A.S. Glicksman, and J.T. Leith, Cancer Res. 44, 4942 (1984).

${ }^{16}$ A.R. Kennedy and M.C. Symons, Carcinogenesis 8, 683 (1987).

${ }^{17}$ ICRU, Washingt. (1979).

18 J.A. LaVerne and S.M. Pimblott, Radiat. Res. 141, 208 (1995).

${ }^{19}$ V. Cobut et al., Radiat. Phys. Chem. 51, 229 (1998).

${ }^{20}$ P. O’Neill, Adv. Space Res. 14, 221 (1994).

${ }^{21}$ J.D. Chapman, D.L. Dugle, A.P. Reuvers, C.J. Gillespie, and J. Borsa, (1975).

22 J.D. Chapman, A.P. Reuvers, J. Borsa, and C.L. Greenstock, Radiat. Res. 56, 291 (1973).

${ }^{23}$ E.N. Gate, M.D. Threadgill, M.F.G. Stevens, D. Chubb, L.M. Vickers, S.P. Langdon, J.A. Hickman, and A. Gescher, J. Med. Chem. 29, 1046 (1986).

${ }^{24}$ D. Newell, A. Gescher, S. Harland, D. Ross, and C. Rutty, Cancer Chemother. Pharmacol. 19, 91 (1987).

${ }^{25}$ A.H. Soloway, R.J. Brumbaugh, and D.T. Witiak, J. Theor. Biol. 102, 361 (1983).

${ }^{26}$ A.L. Ruchelman, P.J. Houghton, N. Zhou, A. Liu, L.F. Liu, and E.J. LaVoie, J. Med. Chem. 48, 792 (2005).

${ }^{27}$ R.S. Gohlke and F.W. McLafferty, Anal. Chem. 34, 1281 (1962).

${ }^{28}$ K. Levsen and F.W. McLafferty, J. Am. Chem. Soc. 96, 139 (1974).

${ }^{29}$ A.G. Loudon and K.S. Webb, Org. Mass Spectrom. 12, 283 (1977).

${ }^{30}$ E.P. Wigner, Phys. Rev. 73, 1002 (1948).

${ }^{31}$ M.J. Frisch, G.W. Trucks, H.B. Schlegel, G.E. Scuseria, M.A. Robb, J.R. Cheeseman, G. Scalmani, V. Barone, B. Mennucci, G.A. Petersson, H. Nakatsuji, M. Caricato, X. Li, H.P. Hratchian, A.F. Izmaylov, J. Bloino, G. Zheng, J.L. Sonnenberg, M. Hada, M. Ehara, K. Toyota, R. Fukuda, J. Hasegawa, M. Ishida, T. Nakajima, Y. Honda, O. Kitao, H. Nakai, T. Vreven, J.A. Montgomery Jr., J.E. Peralta, F. Ogliaro, M. Bearpark, J.J. Heyd, E. Brothers, K.N. Kudin, V.N. Staroverov, R. Kobayashi, J. Normand, K. Raghavachari, A. Rendell, J.C. Burant, S.S. Iyengar, J. Tomasi, M. Cossi, N. Rega, J.M. Millam, M. Klene, J.E. Knox, J.B. Cross, V. Bakken, C. Adamo, J. Jaramillo, R. Gomperts, R.E. Stratmann, O. Yazyev, A.J. Austin, R. Cammi, C. Pomelli, J.W. Ochterski, R.L. Martin, K. Morokuma, V.G. Zakrzewski, G.A. Voth, P. Salvador, J.J. Dannenberg, S. Dapprich, A.D. Daniels, Ö. Farkas, J.B. Foresman, J. V Ortiz, J. Cioslowski, and D.J. Fox, Gaussian 09, Revision E.01 (Gaussian Inc., 
Wallingford, CT, 2009).

${ }^{32}$ E.C. Barnes, G.A. Petersson, J.A. Montgomery, M.J. Frisch, and J.M.L. Martin, J. Chem. Theory Comput. 5, 2687 (2009).

${ }^{33}$ J.A. Pople, M. Head-Gordon, and K. Raghavachari, J. Chem. Phys. 87, 5968 (1987).

${ }^{34}$ A.D. Becke, J. Chem. Phys. 98, 5648 (1993).

${ }^{35}$ R. Krishnan, J.S. Binkley, R. Seeger, and J.A. Pople, J. Chem. Phys. 72, 650 (1980).

${ }^{36}$ M.M. Dawley and S. Ptasińska, Int. J. Mass Spectrom. 365-366, 143 (2014).

${ }^{37}$ S.G. Lias, in NIST Chem. WebBook, NIST Stand. Ref. Database Number 69, edited by P.J. Linstrom and W.G. Mallard (National Institute of Standards and Technology, Gaithersburg MD, 20899, n.d.).

${ }^{38}$ G.H. Wannier, Phys. Rev. 90, 817 (1953).

39 T.D. Märk, J. Chem. Phys. 63, 3731 (1975).

${ }^{40}$ J.A. Montgomery, M.J. Frisch, J.W. Ochterski, and G.A. Petersson, J. Chem. Phys. 110, 2822 (1999).

${ }^{41}$ T.G. Wright and T.A. Miller, J. Phys. Chem. 100, 4408 (1996).

${ }^{42}$ L.A. LaPlanche and M.T. Rogers, J. Am. Chem. Soc. 86, 337 (1964).

43 J.F. Lu, Y.F. Wu, Z.Y. Yu, and X.J. Lin, Russ. J. Phys. Chem. A 85, 1384 (2011).

${ }^{44}$ NIST Mass Spec Data Center, S.E. Stein, and Director, Mass Spectra (National Institute of Standards and Technology, Gaithersburg MD, 20899, n.d.).

45 J.R. Reeher, G.D. Flesch, and H.J. Svec, Org. Mass Spectrom. 11, 154 (1976).

${ }^{46}$ C.R. Brundle, D.W. Turner, M.B. Robin, and H. Basch, Chem. Phys. Lett. 3, 292 (1969).

${ }^{47}$ M.A. Baldwin, A.G. Loudon, K.S. Webb, and P.C. Cardnell, Org. Mass Spectrom. 12, 279 (1977).

${ }^{48}$ B.G. Gowenlock, P.P. Jones, and J.R. Majer, Trans. Faraday Soc. 57, 23 (1961). 